\title{
Tectonic evolution of the upper allochthon of the Órdenes complex (northwestern Iberian Massif): Structural constraints to a polyorogenic peri-Gondwanan terrane
}

\author{
Juan Gómez Barreiro* \\ Department of Earth and Planetary Sciences, University of California, 305 McCone Hall, Berkeley, California 94720, USA \\ José R. Martínez Catalán \\ Departamento de Geología, Universidad de Salamanca, Plaza de los Caidos s/n, 37008 Salamanca, Spain \\ Ricardo Arenas \\ Pedro Castiñeiras \\ Jacobo Abati \\ Departamento de Petrología y Geoquímica, Universidad Complutense, José Antonio Novais 2, 28040 Madrid, Spain \\ Florentino Díaz García \\ Departamento de Geología, Universidad de Oviedo, Jesús Arias de Velasco s/n, 33005 Oviedo, Spain \\ Jan R. Wijbrans \\ Department of Isotope Geochemistry, Vrije Universiteit, De Boelelaan 1085, Amsterdam 1081 HV, The Netherlands
}

\begin{abstract}
The upper allochthon of northwest Iberia represents the most exotic terrane of this part of the European Variscan belt. Recent advances in the metamorphic petrology, structural geology, and geochronology of the upper allochthon in the Órdenes complex are integrated into a synthesis of its tectonic evolution, constraining the main tectonothermal events. Important aspects of this synthesis are (1) the interpretation of Cambro-Ordovician magmatism and earliest metamorphic event, as the result of drifting of a peri-Gondwanan terrane; (2) the subsequent shortening and crustal thickening of the terrane related to its subduction and accretion to Laurussia; (3) a younger cycle of shortening and extension resulting from convergence between Laurussia and Gondwana; and (4) the emplacement of this exotic terrane as the upper allochthon, together with underlying ophiolitic and basal allochthons, during the Laurussia-Gondwana collision.

Implications derived from the well-established tectonothermal sequence are discussed in the context of Paleozoic paleogeography and geodynamics. The evolution

of this part of the belt is related first to the closure of the Tornquist Ocean, and later to that of the eastern branch of the Rheic Ocean. Furthermore, the relative paleopositions of the upper allochthon and the Iberian autochthon in northern Gondwana are discussed.
\end{abstract}

Keywords: tectonics, polyorogenic terrane, Variscan orogeny, Gondwana

* E-mail: barreiro@ seismo.berkeley.edu. 


\section{INTRODUCTION}

The reconstruction of Paleozoic continents, intervening oceans and peri-cratonic terranes relies to a great extent on detailed structural and petrologic analyses of exotic terranes occurring around suture zones, as well as on precise age determinations. The Variscan belt of central and western Europe offers the opportunity to study such types of terranes in a strip running from northwest Iberia to the Bohemian Massif through the French Armorican and Central massifs (Fig. 1).

Ophiolitic units mark the closure of a Paleozoic ocean in several of these massifs. In northwest Iberia, allochthonous ophiolitic units highlight a rootless suture above which an exotic terrane, including high- $P$ /high- $T$ eclogites and granulites, occurs. This upper allochthon has been widely studied. It consists of metasediments and igneous felsic, mafic, and ultramafic rocks, with gabbroic and granitic protoliths dated at ca. $500 \mathrm{Ma}$ (Peucat et al., 1990; Dallmeyer and Tucker, 1993; Schäfer et al., 1993; Abati et al., 1999) and also characterized by early Variscan (425$390 \mathrm{Ma}$ ) metamorphism (Schäfer et al., 1993; Santos Zalduegui et al., 1996; Dallmeyer et al., 1997; Ordóñez Casado et al., 2001; Roger and Matte, 2005; Gómez Barreiro et al., 2006; FernándezSuárez et al., 2007).

Units with similar lithologies and ages that have experienced high- $P$ early Variscan metamorphism also exist in the French Central Massif (Ledru et al., 1994; Ploquin and Santallier, 1994; Santallier et al., 1994), the Vosges and the Black Forest (Franke, 2000), the Bohemian Massif (Franke, 2000; Franke and Zelazniewicz, 2000; Crowley et al., 2002), and also in the Alpine basement (Neubauer et al., 1999). Many of these units can be related to the upper Iberian allochthon, and all together might have formed a coherent terrane whose history we are trying to unravel.

In this contribution, detailed tectonometamorphic studies in three units of the upper allochthon of northwest Spain (Abati, 2002; Castiñeiras, 2003; Gómez Barreiro, 2004), combined with $\mathrm{U}-\mathrm{Pb}$ age determinations (Abati et al., 1999), ${ }^{40} \mathrm{Ar} /{ }^{39} \mathrm{Ar}$ dating of regional fabrics (Gómez Barreiro et al., 2006), and structural, thermobarometric and age data from the rest of the Spanish upper allochthon, are integrated in an evolutionary model for this exotic terrane widely represented in the European Variscides.

\section{GEOLOGICAL SETTING}

The allochthonous complexes of northwest Iberia (Fig. 2) form a stack of exotic terranes preserved as megaklippen in structural basins interspersed among migmatite and granite domes that developed during gravitational collapse and extension in advanced stages of the Variscan orogeny (Martínez Catalán et al., 2007). In a way similar to what has been described for the Caledonian belt of Scandinavia (Gee and Sturt, 1985; Roberts and Gee, 1985; Stephens and Gee, 1989; Rey et al., 1997), upper, middle, and basal allochthons were thrust onto the Iberian autochthon (the Central Iberian zone) with an intervening parautochthonous thrust sheet between them (Farias et al., 1987; Ribeiro et al., 1990). Other exotic units of similar meaning have been described in the Ossa-Morena zone, in southwest Iberia (Fig. 1), by Leal et al. (1996), Araújo and Ribeiro (1997), Fonseca (1997), and Fonseca et al. (1999).

There has been some debate concerning the permanence of the autochthon in Gondwana or its individualization as part of the Armorica plate. The Armorica hypothesis (Van der Voo, 1982, 1988 ) is based on paleomagnetism and has been questioned on the same grounds by Kent et al. (1984), Scotese (1984), and Hargraves et al. (1987). Paris and Robardet (1990) and Robardet et al. (1990) argued against a significant separation of Armorica from Gondwana, based on sedimentary and faunal evidence. Robardet $(2002,2003)$ concluded that only models involving a single Rheic Ocean between Gondwana and Laurentia are realistic on the basis of paleogeographic analysis. Moreover, U-Pb dating of detrital zircons in low-grade metasedimentary rocks of the Iberian autochthon ranging in age from the Neoproterozoic to the Early Devonian have yielded the same age populations, suggesting a common source area during the whole Paleozoic and militating against microplate separation (Fernández-Suárez et al., 2000, 2002a,b; Martínez Catalán et al., 2004).

Turning back to the exotic terranes of northwest Iberia, the middle allochthon consists entirely of ophiolites. Two different origins and ages have been proven for the several existing ophiolitic units (Díaz García et al., 1999a; Pin et al., 2002; Arenas et al., 2004, 2007; Sánchez Martínez et al., 2007), representing different oceanic lithospheres formed at different stages inside the Rheic oceanic realm.

Both the parautochthon and the basal allochthon are considered Gondwanan pieces that never abandoned the northern margin of the continent. Conversely, the upper allochthon clearly represents an exotic terrane, as demonstrated by the structurally underlying ophiolites. However, it is considered to have a Gondwanan origin because the oldest ages obtained from upper intercepts and inherited zircons from orthogneisses, paragneisses, and metabasites (between 2.7 and $1.8 \mathrm{Ga}$; Kuijper, 1980; Peucat et al., 1990; Dallmeyer and Tucker, 1993; Schäfer et al., 1993) are similar to those found in the orthogneisses of the basal allochthon 


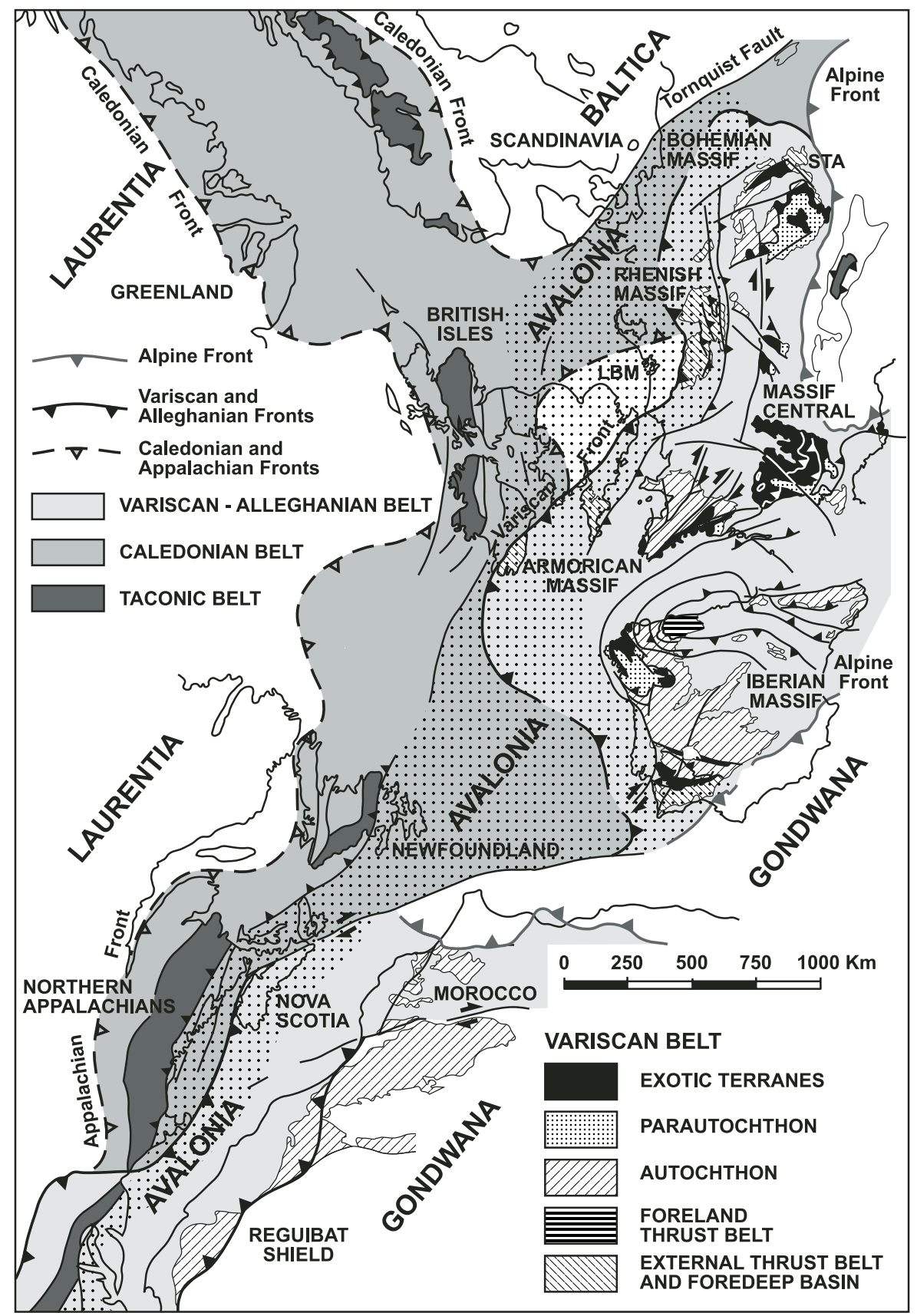

Figure 1. Sketch showing the position of Iberia in relation with the Appalachian, Caledonian, and Variscan belts at the end of the Paleozoic convergence. The continents involved in the successive collisions and the main massifs of the European Variscides are also indicated. LBMLondon-Brabant Massif; STA-Silesian terrane assemblage; stippled area-Avalonia. Modified from Martínez Catalán et al. (2002) and based on Neuman and Max (1989).

(1.8 Ga; Santos Zalduegui et al., 1995) and of the autochthon (Lancelot et al., 1985; Gebauer, 1993). And they are also similar to those of northern Africa, including the west African craton and the Saharan basement remobilized during the pan-African orogeny (Caby, 1989; Rocci et al., 1991; Avigad et al., 2003).

These similarities point to a common Gondwanan basement for the upper and basal allochthons and for the Iberian autochthon. Moreover, graywackes from low-grade metasediments of the uppermost unit in the Órdenes complex have been investigated for detrital zircon ages, yielding three age populations of
2.5-2.4 Ga, 2.1-1.9 Ga, and 610-480 Ma (Fernández-Suárez et al., 2003), which record the major events in the west African craton of northern Gondwana and the surrounding pan-African belts (Caby, 1989; Rocci et al., 1991).

Notably, the Neoproterozoic to Early Devonian sediments of the autochthon underlying the complexes have yielded detrital zircons with similar age populations and, in addition, a Mesoproterozoic (1.2-0.9 Ga) age cluster (Fernández-Suárez et al., 1999, 2000, 2002a,b; Martínez Catalán et al., 2004). These age data suggest that even if the upper allochthon is a terrane drifted away 

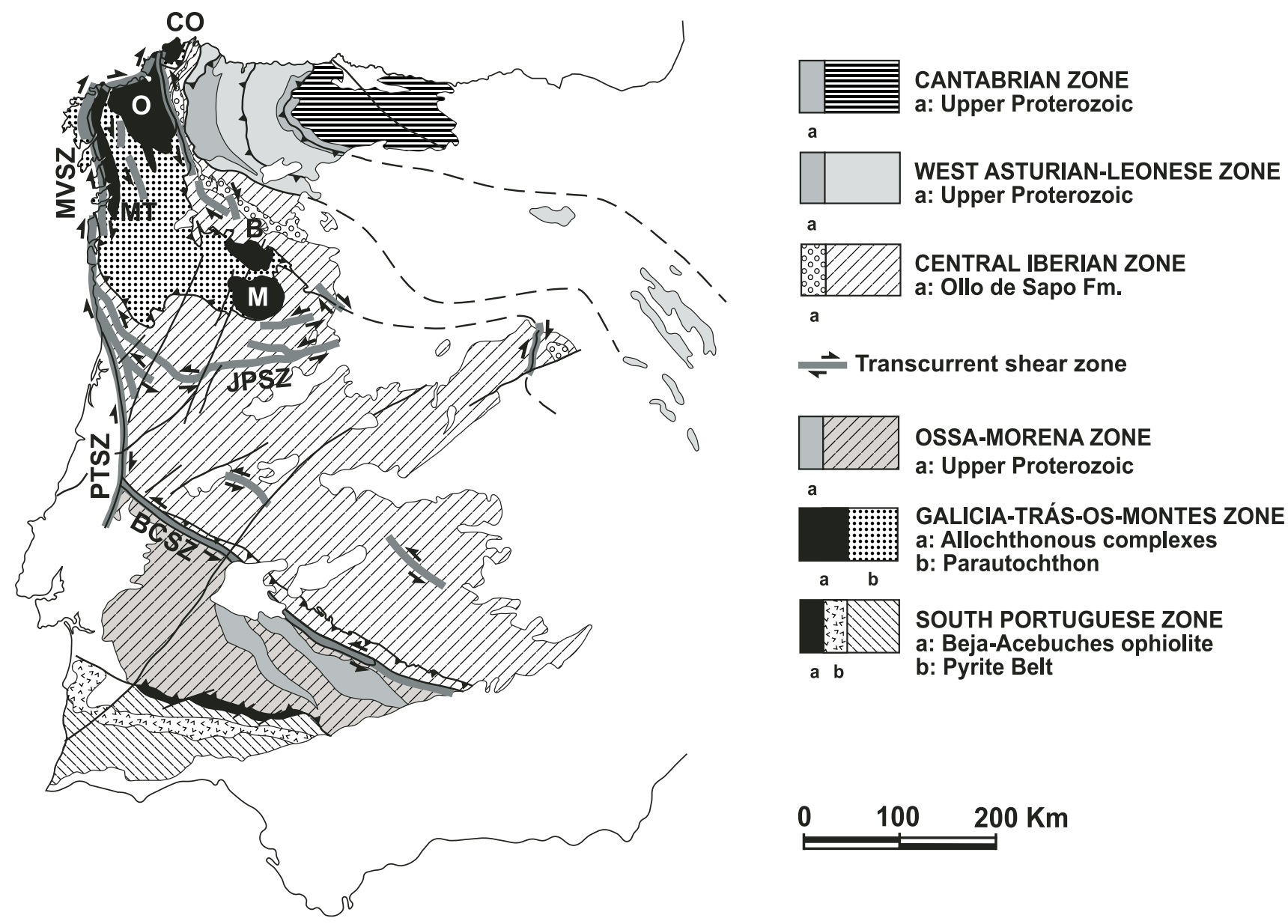

Figure 2. The Iberian Massif showing the subdivision in zones, based on Julivert et al. (1972) and Farias et al. (1987). Allochthonous complexes of northwest Iberia: B-Bragança; CO_Cabo Ortegal; M-Morais; MT_Malpica-Tui; O—Órdenes. Transcurrent shear zones: BCSZ—Badajoz-Córdoba shear zone; JPSZ—Juzbado-Penalva shear zone; MVSZ—Malpica-Vigo shear zone; PTSZ—Porto-Tomar shear zone.

from Gondwana and later emplaced on it, the site of derivation differs from that of emplacement.

Late Cambrian to Early Ordovician magmatism is widespread in the upper and basal allochthons and also in the autochthon, being a little older in the upper allochthon (ca. $500 \mathrm{Ma}$; Dallmeyer and Tucker, 1993; Abati et al., 1999) than in the basal allochthon and the autochthon (490-470 Ma; Van Calsteren et al., 1979; García Garzón et al., 1981; Vialette et al., 1987; Gebauer, 1993; Santos Zalduegui et al., 1995; Valverde Vaquero and Dunning, 2000). That magmatism has calcalkaline and arc affinities in the autochthon (Ortega et al., 1996), in some upper allochthonous units and in many granitoids of the basal allochthon, but some granites and mafic rocks of the latter are alkaline to per-alkaline (Floor, 1966; Pin et al., 1992).

The problem is to reconcile the tectonic stability registered by the Early Ordovician sediments of the autochthon, typical of a passive margin, the alkaline, rift-related magmatism of the basal allochthon, the widely accepted Early Paleozoic terrane dispersion in the peri-Gondwanan realm, and the calcalkaline and arc affinities in the upper allochthon and the autochthon. Valverde Vaquero and Dunning (2000) have suggested that rifting was located in a back-arc setting behind a subduction zone. This hypothesis is supported by Stampfli and Borel (2002), Stampfli et al. (2002), Winchester et al. (2002), and von Raumer et al. (2003) in their reconstructions of the peri-Gondwanan terranes and implies that rolling back of the subducting slab of a wide ocean may have pulled the future upper allochthonous terrane apart from Gondwana, as the subduction of the southern Iapetus margin did with Avalonia.

\section{THE UPPER ALLOCHTHON IN THE ÓRDENES COMPLEX}

Different tectonic units can be distinguished in the upper allochthon, being separated from each other by faults, often extensional detachments (Martínez Catalán et al., 2002). These units can be grouped, according to their metamorphic imprint, into two different sets: (1) high- $P /$ high- $T$ units, and (2) intermediate- $P$ 
units. Both sets exist in the Spanish allochthonous complexes of Cabo Ortegal and Órdenes (Fig. 2). The first set is better exposed in Cabo Ortegal, where very good samples of high- $P /$ high- $T$ fabrics have been preserved (Abalos et al. 1996; Abalos, 1997; Abalos and Aranguren, 1998). The second set shows its best outcrops in Órdenes (Martínez Catalán et al., 2002).

The high- $P$ /high- $T$ units occupy a lower structural position below the intermediate- $P$ units (Fig. 3), the contact being systematically of extensional character (Díaz García et al., 1999b; Castiñeiras, 2003; Gómez Barreiro, 2004; González Cuadra, 2005). Any indication of a possible suture between both sets is lacking, so that they are considered as parts of the same tectonostratigraphic terrane in spite of their different metamorphic evolutions. Actually, their metamorphic evolutions show a complementary history for both sets, thermobarically converging when approaching the transition zone, that is, the detachment separating them. These zones of contact may show a subsequent record of overprinting events and reworking (Gómez Barreiro, 2004).

Our study focuses on the Órdenes complex, the largest (135 by $75 \mathrm{~km}$ ) of the klippen containing exotic terranes in northwest Iberia. Detailed descriptions and interpretations of many of its units corresponding to the upper allochthon have been published elsewhere (Van Zuuren, 1969; Hubregtse, 1973; Díaz García, 1990; Abati et al., 1999, 2003; Díaz García et al., 1999b; Andonaegui et al., 2002; Arenas and Martínez Catalán, 2002). Figure 3 shows a simplified geological map of the complex and a schematic cross-section. For a more detailed map and structural description, the reader is referred to Martínez Catalán et al. (2002). Figure 4 depicts a cross-section representing lithologies of the upper allochthonous units together with protolith and metamorphic ages, whereas Figure 5 shows the same section with the maximum metamorphic grade reached by the different units and the $P$ - $T$ paths established for several of them.

As can be seen in Figure 5, metamorphism increases from top to bottom, from greenschist to high- $T$ eclogite facies, although the transition, far from being gradual, is accomplished via discrete extensional detachments. Furthermore, because of the lenticular rather than tabular character of many units, rocks with a great difference in their peak $P-T$ conditions occur adjacent to one another. The fact that units with differences of more than $1.2 \mathrm{GPa}$ in their pressure peak occur presently in a sheet $\sim 10 \mathrm{~km}$ thick indicates that the original pile has been largely attenuated.

The units of Betanzos, O Pino, Corredoiras, and Monte Castelo are of the intermediate- $P$ type, whereas those of Fornás, Arinteiro, Belmil, Melide, and Sobrado correspond to the high$P /$ high- $T$ type. A brief description of each unit follows, given in descending order of what supposedly was their original structural position within the orogenic wedge. Protolith ages and depositional age constraints are given, when available, whereas metamorphic ages are presented and discussed later, together with the tectonometamorphic evolution.

The Betanzos unit consists of a monotonous succession of slates and metagraywackes with turbiditic characteristics and also contains minor quartzites, conglomerates, and diabase dikes.
Graywackes are feldspathic with a framewok of quartz and fresh plagioclase. Rock fragments with vitric and microgranular textures are common in the polymictic conglomerates and coarsegrained graywackes, together with slates, cherts, and clasts of bipyramidal quartz. The abundance of volcanic components suggests a volcanic environment. The metagraywackes have been investigated for detrital zircon ages, yielding three age populations of 2.5-2.4 Ga, 2.1-1.9 Ga, and 610-480 Ma (FernándezSuárez et al., 2003), which establishes a maximum depositional age at the Early-Middle Ordovician transition. The sediments were affected by greenschist-facies metamorphism and by early recumbent and late upright folds (Matte and Capdevila, 1978).

O Pino unit is a thick pile of mesozonal monotonous schists and paragneisses intruded by relatively small bodies of gabbro and granitoids. It overlies the huge meta-igneous massifs that form the two underlying units. This is a Barrovian-like pile, with metamorphic zones ranging from almandine to sillimanite (Abati, 2002; Castiñeiras, 2003). Monazites from semipelitic paragneisses of the sillimanite zone have yielded ages of 493 \pm 1.3 and $496 \pm 3 \mathrm{Ma}$ (Abati et al., 1999).

The Corredoiras unit is a coarse-grained, massive metagranodiorite and subordinate tonalite, whose crystallization is dated at $500 \pm 2 \mathrm{Ma}$ (U-Pb dating on zircons; Abati et al., 1999). The massif is variably gneissified and kilometer-scale xenoliths of metasediments occur inside the orthogneisses. The xenoliths appear frequently migmatized, but also locally granulitized, with a paragenesis indicative of the intermediate- $P$ granulite facies (González Cuadra, 2005). This high-grade, intermediate- $P$ metamorphism affected the whole unit.

The Monte Castelo unit is a two-pyroxene gabbro of tholeiitic character, similar in composition to modern island arc basalts (Andonaegui et al., 2002). The presence of olivine and the common ophitic textures point to a relatively shallow emplacement. U-Pb analyses on zircons yielded an age of 499 \pm 2 Ma for crystallization of the protolith (Abati et al., 1999). Scarce metapelitic intercalations and a kilometer-scale shear zone inside the mostly undeformed gabbro developed intermediate- $P$ granulite-facies parageneses. This unit is considered the lowermost intermediate- $P$ unit and, although it reached granulite facies, its metamorphic gradient was never of the high- $P$ type (Abati, 2002; Abati et al., 2003).

The Fornás and Arinteiro units are similar, the latter being a horse of the former sandwiched between thrust faults. They consist of heterogeneous and well-foliated amphibolites. Van Zuuren (1969) described preserved igneous textures, indicating a gabbroic origin, and also granulite-facies relics, which have been confirmed by Gómez Barreiro (2004). The dominant amphibolite-facies foliation developed subsequently, during the exhumation, in an extensional shear zone that drove the unit into contact with the overlying mesozonal schists and paragneisses of the O Pino unit. This shear zone, known as the Fornás detachment, was subsequently affected by recumbent folds, repeated by thrusts, and back-folded during the motion of the younger Bembibre-Pico Sacro extensional detachment (Figs. 3 and 4). Fornás 
VARISCAN GRANITOIDS

\begin{tabular}{ll} 
& Migmatites \\
\hline+ & Two-mica aluminous granites \\
\hline$+\ldots+7$ & Synkinematic granodiorites
\end{tabular}

\section{"RDENES COMPLEX UPPER ALLOCHTHON Intermediate- $P$ units}

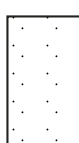

BETANZOS UNIT

Metagraywackes, slates, phyllites, conglomerates, and quartzites

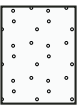

O PINO UNIT

Medium to high-grade schists and paragneisses

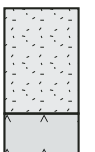

MONTE CASTELO AND CORREDOIRAS UNITS Orthogneisses Metagabbros

\section{High- $P$ / high- $T$ units} FORNiS, SOBRADO, BELMIL AND MELIDE UNITS

Paragneisses, amphibolites, basic granulites, eclogites and ultramafic rocks

\section{OPHIOLITIC ALLOCHTHON}

CARE"N AND BAZAR UNITS

Flasergabbros, amphibolites and ultramafic rocks

VILA DE CRUCES UNIT

Greenschist-facies metabasites, phyllites and schists

\section{BASAL ALLOCHTHON}

AGUALADA, SANTIAGO, FORCAREI AND LALÕN UNITS

Schists, albitic schists, paragneisses,

amphibolites and felsic orthogneisses

\section{PARAUTOCHTHON}

\section{SCHISTOSE DOMAIN}

Schists, carbonaceous schists, and metaquartzites
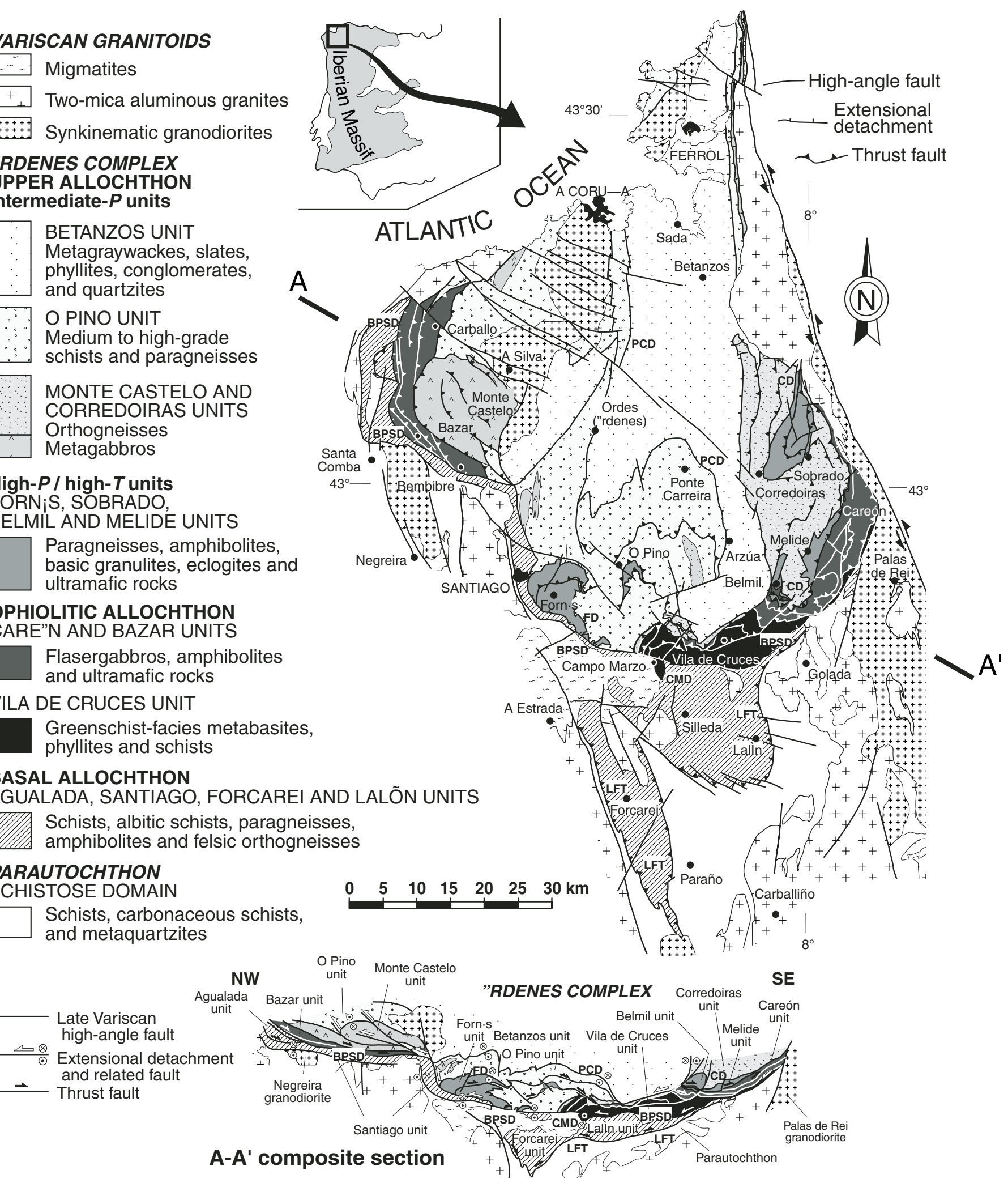

Figure 3. Geological map and cross-section (A-A') of the Órdenes complex (northwest Spain) showing the allochthonous units and the main faults. BPSD—Bembibre-Pico Sacro detachment; CD—Corredoiras detachment; CMD—Campo Marzo detachment; FD—Fornás detachment; PCD—Ponte Carreira detachment; LFT—Lalín-Forcarei thrust. 


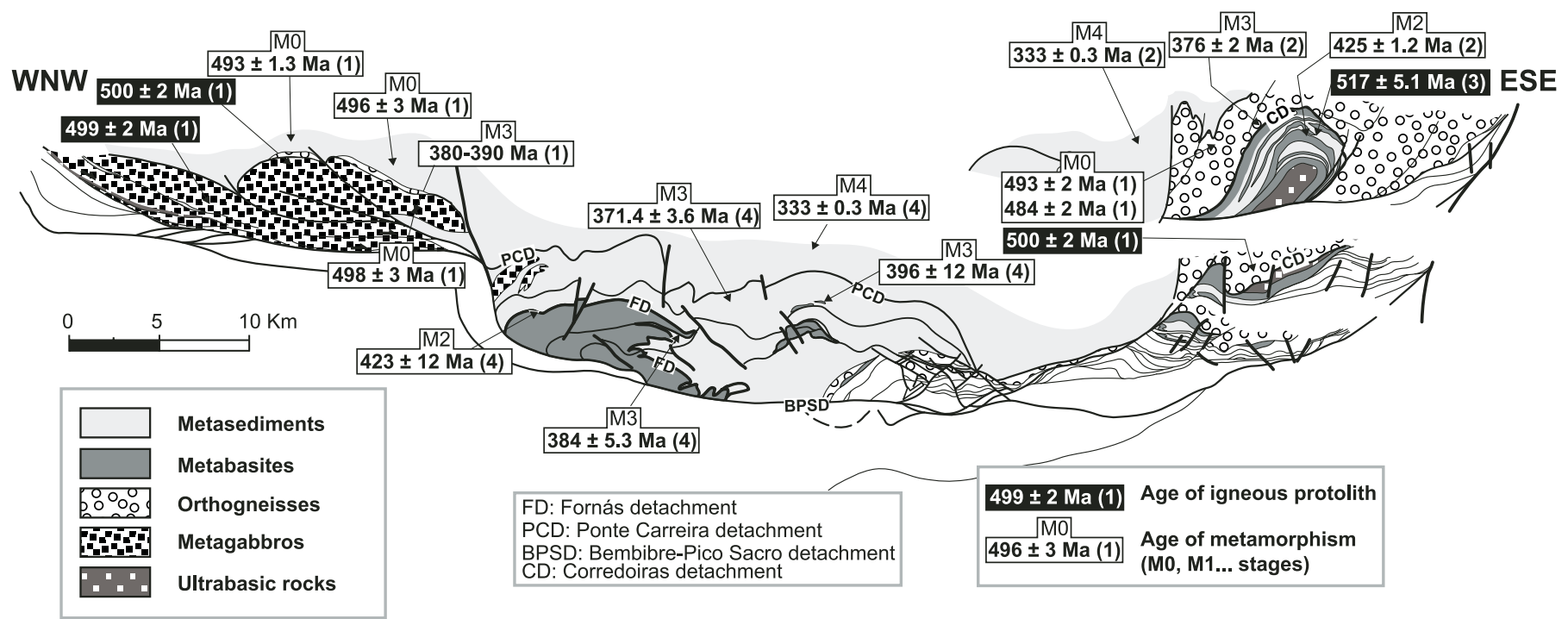

Figure 4. Distribution of the main lithologies of the upper allochthon in a cross-section of the Órdenes complex and published isotopic ages of igneous protoliths (black box) and regional fabrics (white box), with indications of the corresponding metamorphic stage. Numbers in parenthese refer to references: 1—Abati et al. (1999); 2-Dallmeyer et al. (1997); 3-Fernández-Suárez et al. (2007); 4—Gómez Barreiro (2004).

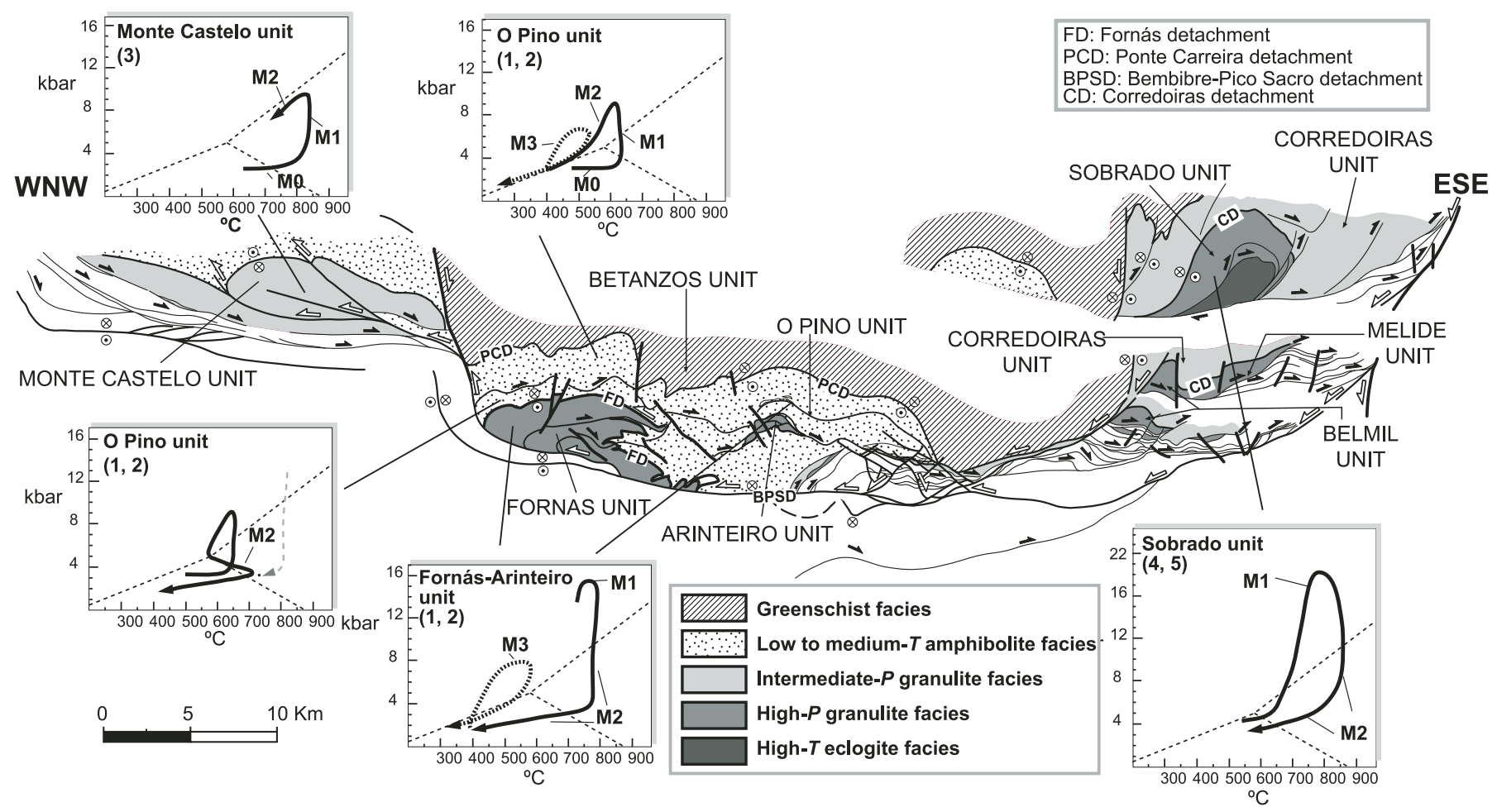

Figure 5. Distribution of the maximum metamorphic grade reached by the units of the upper allochthon in a cross-section of the Órdenes complex and published pressure-temperature paths for several units. Dashed lines in $P$ - $T$ diagrams represent aluminum silicate phase diagram after Holdaway (1971). Numbers in parenthese refer to references: 1-Castiñeiras (2003); 2-Gómez Barreiro (2004); 3-Abati et al. (2003); 4-Arenas and Martínez Catalán (2002); 5-Díaz García et al. (1999b). 
is the uppermost high- $P /$ high- $T$ unit and the one in which the high-pressure parageneses (Van Zuuren, 1969; Gómez Barreiro, 2004) have been less preserved by the subsequent amphibolitefacies evolution.

The Belmil, Melide, and Sobrado units are very similar, and also equivalent to high- $P /$ high- $T$ units in the Cabo Ortegal complex, where they have been widely studied. They consist of paragneisses and mafic and ultramafic meta-igneous rocks. Mafic rocks derive from gabbros of tholeiitic composition whose geochemical signature has been compared to mid-ocean ridge basalt (MORB; Gil-Ibarguchi et al., 1990) and related with continental rifting (Galán and Marcos, 1997). Conversely, geochemical studies in the ultramafic rocks of Cabo Ortegal point to a suprasubduction origin for these pyroxenite-rich peridotites at ca. $500 \mathrm{Ma}$ (Santos et al., 2002). The mafic igneous protoliths have been dated at 520-480 Ma (Peucat et al., 1990; Ordóñez Casado et al., 2001; Fernández-Suárez et al., 2007). Field and map relationships show that they intruded the sedimentary precursor of the paragneisses. These have yielded U-Pb sensitive high-resolution ion microprobe (SHRIMP) core ages clustering around 2.0-2.2 Ga and $540 \mathrm{Ma}$, with the youngest detrital zircon dated at $507 \mathrm{Ma}$ (Schäfer et al., 1993), thus establishing a Late Cambrian maximum depositional age.

The metabasites include garnet-clinopyroxene granulites and eclogites, retrograded to the amphibolite facies (Vogel, 1967; Hubregtse, 1973). In Sobrado, gabbros occur in several stages of transformation, from practically undeformed and scarcely affected by the metamorphism to coronitic metagabbros and high- $P$ granulites. In the less-deformed gabbros, subophitic and diabase textures have been preserved, indicating an emplacement at relatively shallow crustal levels (Arenas and Martínez Catalán, 2002). The tectonothermal evolution includes an old high- $P$ granulite to eclogite facies metamorphism, followed by decompression and partial melting and then, successively, by a penetrative mylonitization in the amphibolite facies, recumbent folding, and thrusting in the greenschist facies (Vogel, 1967; Gil-Ibarguchi et al., 1990; Arenas, 1991; Girardeau and Gil-Ibarguchi, 1991; Mendia Aranguren, 2000; Marcos et al., 2002).

\section{TECTONOMETAMORPHIC EVOLUTION}

The following evolution has been deduced from detailed studies of the O Pino, Monte Castelo, and Fornás units, and this description focuses on the extensional detachments separating them. The combined investigation of large structures and thin sections with thermobarometric and age determinations have revealed complex $P-T$ paths characterized by two loops, the first of which is counterclockwise for the intermediate- $P$ units (Fig. 5). This fact provides the guideline for the following description, which splits the metamorphic and deformational history into six correlative tectonothermal stages contemporaneous with plate convergence, and a previous one related to terrane individualization.

\section{D0-M0: A Thermal Event Related to Magmatism}

The oldest structural and metamorphic relicts in the O Pino unit are mesoscopic veins with andalusite and quartz that show prekinematic relationships with the first identified tectonic foliation and are preserved in some pelitic gneisses. These veins have been related to low- $P$ heating and linked to the intrusion of huge plutonic massifs, such as those partially preserved in the Monte Castelo and Corredoiras units. Consequently, the oldest loop of the metamorphic $P-T$ path is drawn starting with isobaric heating related to intrusion of massive gabbro and granodiorite bodies (Abati et al., 2003; Castiñeiras, 2003). Pressure and maximum temperature reached in this stage in the Monte Castelo unit have been estimated by Abati et al. (2003) to be $4-6 \mathrm{kbar}$ and $800{ }^{\circ} \mathrm{C}$.

Monazite included in biotite in large enclaves of pelitic composition yielded ages of $498 \pm 2 \mathrm{Ma}$ in the Monte Castelo gabbro and $493 \pm 2$ and $484 \pm 2 \mathrm{Ma}$ in the Corredoiras orthogneiss (Abati et al., 1999), close to the age of the host plutonic rocks (499 \pm 2 and $500 \pm 2 \mathrm{Ma}$, respectively). The arc affinities of the Monte Castelo gabbro (Andonaegui et al., 2002) together with the immature character of the graywackes of the Betanzos unit and their high content in volcanogenic fragments suggest a relationship of isobaric heating with magmatic underplating and massive gabbro and granodiorite-tonalite intrusion in relatively shallow crustal levels of a magmatic arc. Contemporaneous partial melting of metasediments is documented by a granitoid rich in pelitic enclaves occurring at the roof of the Monte Castelo gabbro and dated at $500 \pm 2 \mathrm{Ma}$ (Abati et al., 1999).

The previous data pertain to the intermediate- $P$ units. Although in the high- $P /$ high- $T$ units the mafic protoliths have the same Cambro-Ordovician ages, their geochemistry points rather to continental rifting (Galán and Marcos, 1997). This rifting is not in conflict with the arc affinities of the overlying units, as both can be integrated in the picture of a terrane drifting away from Gondwana and pulled by slab roll-back of a subduction zone that provides the arc-related magmatism (Fig. 6).

\section{D1-M1: First Burial by Crustal Thickening and Subduction}

The first thermal event D0-M0 was followed by pressurization related to the accretion of the upper allochthon to an active orogenic wedge (Martínez Catalán et al., 1997, 1999). Both sets of the upper allochthon reached metamorphic peak conditions during this event.

In the intermediate- $P$ units, the regional foliation (S1) developed, varying from slaty cleavage at the uppermost levels to gneissic layering at depth as metamorphic grade increased (Díaz García, 1990; Abati, 2002; Castiñeiras, 2003; Gómez Barreiro, 2004). Petrographic evidence suggests that rocks were pressurized following an isothermal path according to Abati et al. (2003) and Castiñeiras (2003), reaching peak conditions of $550-800{ }^{\circ} \mathrm{C}$ and 8-11 kbar.

In the high- $P /$ high- $T$ units, granulite and eclogite assemblages developed, with peak conditions ranging between 12 and 


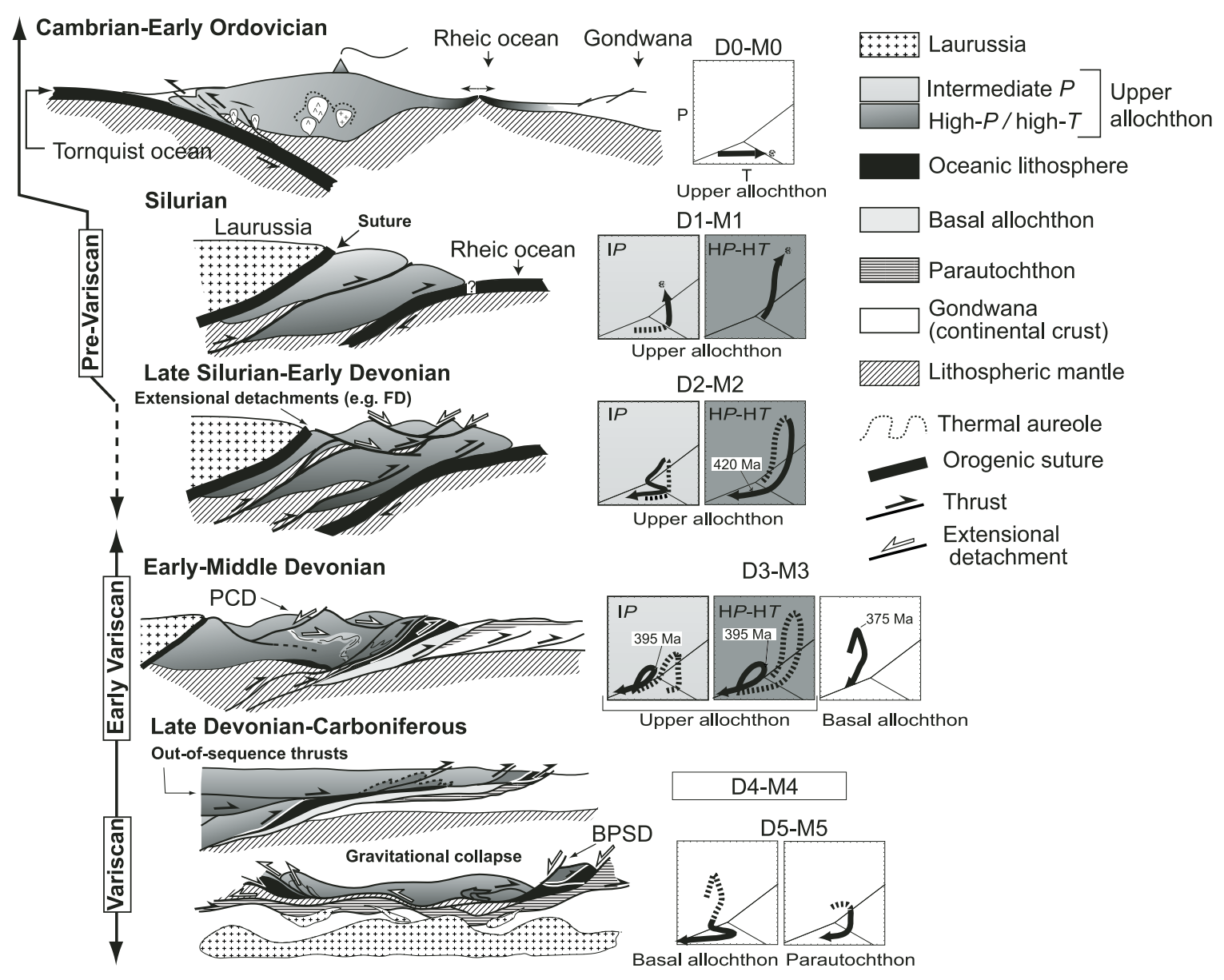

Figure 6. Tectonothermal evolution of the allochthonous units of the Órdenes complex, according to the proposed three cycles of convergence and exhumation. (1) Pre-Variscan convergence: D0-M0, formation of a volcanic arc at the northern active margin of Gondwana. D1-M1, accretion of the arc to the northern margin of the Rheic Ocean. D2-M2, tectonic exhumation of the units by extensional detachments. (2) Early Variscan convergence: D3-M3, continued development of the orogenic wedge by understacking of the ophiolitic and basal units, resulting in a new stage of burial and exhumation. (3) Variscan convergence: D4-M4 and D5-M5, representing the final stages of emplacement of the allochthonous complexes, including the gravitational collapse of the orogen. IP - intermediate pressure. Other abbreviations as in Figure 3.

$22 \mathrm{kbar}$ and $750-800{ }^{\circ} \mathrm{C}$ (Mendia Aranguren, 2000; Arenas and Martínez Catalán, 2002). High-P/high- $T$ fabrics were well preserved in the lowermost units (Sobrado and Belmil units, and also in the Cabo Ortegal complex), whereas in the Fornás and Arinteiro units, D2-M2 retrogression became nearly complete, with D1-M1 association and fabric preserved only in rare, decimeter-scale lenses (Gómez Barreiro, 2004). Differences in the metamorphic gradients experienced by the upper allochthonous units (high- $P$ versus intermediate- $P$ ) probably reflect the individualization of two or more tectonic units that underwent different degrees of underthrusting and subduction (Fig. 6).

This stage has eluded attempts to establish its age. In the high- $P /$ high- $T$ set, it has been dated in the same units and even with the same samples, at 500-480 Ma (conventional U-Pb isotope dilution and thermal ionization mass spectrometry [IDTIMS]; Peucat et al., 1990; Fernández-Suárez et al., 2002c) and
395-390 Ma (U-Pb SHRIMP; Schäfer et al., 1993; Ordóñez Casado et al., 2001), whereas in the intermediate- $P$ units, monazite ages of 500-490 Ma were interpreted to reflect its age (Abati et al., 1999). If the older ages are those of D1-M1 event, they would imply burial of the upper allochthon closely following or even contemporaneous with widespread gabbro-granodiorite magmatism. Conversely, if the younger ages are correct, they would place D1-M1 temporally far from that Cambro-Ordovician magmatic cycle and in an early Variscan context.

Additional information is given by ${ }^{40} \mathrm{Ar} /{ }^{\beta 9} \mathrm{Ar}$ analyses in hornblendes of D2-M2 amphibolites retrogressive after high- $P$ granulites, yielding ages of ca. 425-410 Ma (Dallmeyer et al., 1997; Gómez Barreiro et al., 2006). If correct, these data would discard the Early Devonian age (395-390 Ma) for the high- $P$ / high- $T$ event but would not necessarily imply that the CambroOrdovician age is correct. 
A recent secondary ion mass spectrometry (SIMS) U-Pb study of zircons from gabbros, mafic granulites, and migmatitic leucosomes was carried out by Fernández-Suárez et al. (2007), finding that new zircon was growing since at least $410 \mathrm{Ma}$, in close relation to partial melting. As it is widely accepted that all high- $P$ /high- $T$ units underwent partial melting after having reached their pressure peak (Arenas, 1991; Arenas and Martínez Catalán, 2002), this observation again militates against the Early Devonian age for the D1-M1 stage. The new SIMS data are in accordance with the ${ }^{40} \mathrm{Ar} /{ }^{39} \mathrm{Ar}$ analyses and, together, indicate that the peak pressure was reached before 410 , and possibly, $425 \mathrm{Ma}$.

\section{D2-M2: Early Exhumation}

The thickened pile led to gravitational instabilities, resulting in several major extensional detachments in the upper allochthon (Gómez Barreiro, 2004). The best example is the Fornás detachment, marking the contact between the high- $P /$ high- $T$ units and the intermediate- $P$ units in the southwest of the Órdenes complex (Figs. 3-5).

A strong regional fabric (S2) developed in the footwall to the detachment (Fornás and Arinteiro units) under amphibolitefacies conditions. The $P-T$ evolution shows isothermal decompression at over $700{ }^{\circ} \mathrm{C}$, which led to partial melting (Gómez Barreiro, 2004) and, subsequently, the roof of the units recorded nearly isobaric cooling at low pressures $(<4 \mathrm{kbar})$. Tectonites developed during decompression are banded mylonites, showing strong shape and crystallographically preferred orientation of amphibole, pyroxene, plagioclase, and quartz, which defines the foliation and a persistent NNW-SSE mineral lineation. Kinematic analysis of the Fornás detachment has revealed a top-tothe-NNW sense of shear (Gómez Barreiro, 2004). Taking into account microstructural features and petrofabric analyses, deformation progressed under conditions bracketed between 750 and $300{ }^{\circ} \mathrm{C}$ (Gómez Barreiro, 2004).

At the hangingwall to the $\mathrm{D} 2$ detachment (O Pino unit), the thermal effects were restricted to the first few meters above the contact, where heat transfer was operative. The rocks experienced heating under low- $P$ and high- $T$ conditions (Fig. 5). Synkinematic leucosomes and mylonites developed at the bottom of the hangingwall, showing a NNW-SSE mineral lineation and kinematic criteria indicating a top-to-the-NNW sense of shear (Gómez Barreiro, 2004).

M2 retrogression in the hangingwall to the Fornás detachment completes the counterclockwise loop of the $P$ - $T$ path in the intermediate- $P$ units. In the high- $P /$ high- $T$ units, the geometry of the M1 part of the loop is constrained by $P-T$ conditions deduced from thermobarometry carried out in granulites and eclogites and from corona reactions in granulitic metagabbros of the Sobrado unit (Arenas and Martínez Catalán, 1993, 2002). The M2 part is taken from Díaz García et al. (1999b). In this case, the burial and decompressive trajectories run nearly parallel to each other, not drawing a counterclockwise loop. The first trajectory compares well with the $P-T$ paths modeled for subduction zones by Peacock
(1990, 1991), which are similar, although of opposite sense, to exhumative paths characterized by tectonic denudation followed by erosion, such as $\mathrm{M} 2$ in the $\mathrm{O}$ Pino unit. Laserprobe ${ }^{40} \mathrm{Ar} /{ }^{39} \mathrm{Ar}$ dating of a mylonitic amphibolite from the Fornás detachment constrains its motion around $423 \pm 12 \mathrm{Ma}$ (Gómez Barreiro et al., 2006), in accordance with data collected from other units and described in the previous section.

\section{D3-M3: A New Cycle of Crustal Shortening and Exhumation}

The regional fabrics S1 and S2 were overprinted by prograde contractional shear zones and recumbent folds (Figs. 4 and 5), with a vergence and sense of shear to the northeast and east (Martínez Catalán et al., 2002; Gómez Barreiro, 2004; González Cuadra, 2005). In the southwest of the Órdenes complex, typical shear zones led to amphibolite-facies reequilibration with assemblages containing garnet, plagioclase, hornblende, and zoisite. $P-T$ conditions in the highest-grade shear zones were 6-8 kbar and $500-600{ }^{\circ} \mathrm{C}$ (Castiñeiras, 2003; Gómez Barreiro, 2004). The previous fabrics were transposed by a new schistosity (S3), axial planar to recumbent folds and show a heterogeneous distribution (Gómez Barreiro, 2004). This event represents a new cycle of thickening in the upper allochthon, but new extensional structures also developed. These are the Corredoiras and Ponte Carreira detachments (Figs. 3 and 5), viewed as the result of gravitational readjustments of the orogenic wedge (Martínez Catalán et al., 1996, 2002; Díaz García et al., 1999b). Together the contractional and subsequent extensional structures define a new, clockwise loop in the $P$ - $T$ paths (Gómez Barreiro, 2004).

The timing of the D3-M3 event is constrained by ${ }^{40} \mathrm{Ar} /{ }^{\beta 9} \mathrm{Ar}$ dating. The amphibolite-facies foliation associated with contractional shear zones has yielded 400-380 Ma (Peucat et al., 1990; Dallmeyer et al., 1991; Gómez Barreiro et al., 2006), whereas the foliation in the extensional detachments of Corredoiras and Ponte Carreira were dated at $375 \mathrm{Ma}$ (Dallmeyer et al., 1997) and $371 \mathrm{Ma}$ (Gómez Barreiro et al., 2006), respectively.

These Middle-Late Devonian ages (according to the geological time table of Gradstein et al., 2004) are coeval with regional amphibolite-facies foliation in the underlying ophiolitic units, where it is also related to thrusting and imbrication (Díaz García et al., 1999a). These contractional structures led to the closure of the oceanic domain between the upper and basal allochthons. Subduction of the latter, thought to represent the outermost edge of the Gondwanan continental margin, has been dated at 385$375 \mathrm{Ma}$ using ${ }^{40} \mathrm{Ar} /{ }^{39} \mathrm{Ar}$ geochronology (Rodríguez et al., 2003). Probably, underthrusting of this continental basement triggered extension of the overlying orogenic wedge, giving rise to the Corredoiras and Ponte Carreira detachments.

\section{D4-M4: Emplacement of the Exotic Terranes}

The exotic terranes were emplaced following pervasive deformation in the autochthon, which gave rise to recumbent folds with axial planar cleavage dated at $359 \mathrm{Ma}$ in the inner parts 
of the belt, close to the allochthonous complexes, and $336 \mathrm{Ma}$ in more external areas (Dallmeyer et al., 1997). The emplacement occurred in more than one step, with the basal allochthon emplaced first along the Lalín-Forcarei thrust above the parautochthon (Fig. 3) at $340 \mathrm{Ma}$, probably carrying the ophiolites and upper allochthon piggy-back. This movement was followed by renewed thrusting of the two latter at ca. 330-320 Ma (Dallmeyer et al., 1997; Martínez Catalán et al., 2002).

The younger thrusts cut across older contractional faults related to the stacking of the different exotic terranes and represent an out-of-sequence thrust system. These thrusts show a topto-the-southeast sense of motion and affected mainly the base of the upper allochthon and the ophiolites. No thermal effects were detected in the upper units, and only retrograde metamorphism occurred in the thrust surface, at very low- $T$ conditions. In the uppermost units, a low-grade crenulation cleavage dated at 330 Ma (Dallmeyer et al., 1997; Gómez Barreiro et al., 2006) is probably related to the activity of the out-of-sequence thrusts.

\section{D5-M5: Late Orogenic Collapse}

Following the D4 contractional event and pervasive shorthening and thickening in the underlying autochthon, gravitational disequilibrium led to renewed gravitational adjustments, giving rise to the Bembibre-Pico Sacro detachment, a complex extensional system that partially reactivated previous out-of-sequence thrusts. Detailed kinematic analysis reveals a shear zone with a general top-to-the-northwest sense of shear. The activity of the Bembibre-Pico Sacro detachment was contemporaneous with extensive melting in the footwall and the establishment of a high- $T$ and low$P$ gradient (Gómez Barreiro et al., 2002; Gómez Barreiro, 2003), which suggests that the detachment was related to the late gravitational collapse of the orogen (Vanderhaeghe and Teyssier, 2001). The extensive synkinematic magmatism has been dated at 323 $\pm 11 \mathrm{Ma}$ around the Órdenes complex (Bellido et al., 1992).

\section{D6-M6: Late Orogenic Compression}

Upright folds were formed in conjunction with north-south dextral and sinistral strike-slip shear zones (Fig. 2), and highangle faults overprinted the late extensional detachments and the high- $T$ and low- $P$ isograds. Folds with north-south axial surfaces developed in the Órdenes complex in close relation with a sinistral shear zone developed to the east (Fig. 3). These structures suggest a change in the tectonic regime in which transpression represented an important component of shortening (Iglesias Ponce de León and Choukroune, 1980; Llana-Fúnez and Marcos, 2001). Upright folding has been dated in the autochthon at ca. 314 Ma (Capdevila and Vialette, 1970; Ries, 1979).

\section{GEODYNAMIC IMPLICATIONS}

Sedimentary and faunal evidence, detrital zircon analyses, and the failure to find a suture between the hypothetical Armorica plate and Gondwana indicate that the Iberian authochthon formed part of Gondwana during the whole Paleozoic. The basal allochthon represents the outermost edge of the continent, formed after an episode of continental rifting during the Early Ordovician. That was the time of separation of Avalonia and creation of the Rheic Ocean (Cocks and Fortey, 1988; Scotese and McKerrow, 1990; Winchester et al., 2002) and, for that reason, we suggest that the ocean in front of the Iberian autochthon at that time was also the Rheic or its continuation to the east.

The exotic character of the upper allochthon is well established, and its peri-Gondwanan derivation has been discussed above in the geological setting. Drifting occurred at the CambroOrdovician boundary, so that this terrane could be the piece whose separation created the passive margin nowadays preserved in the basal allochthon. However, differences in the zircon populations of the upper allochthon and the autochthon suggest that this supposition might not be true. In any case, both the upper and basal allochthons probably formed part of what has been termed the "Armorica terrane assemblage" (Franke, 2000; Winchester et al., 2002) even when, according to our interpretation, not all the terranes forming the assemblage did actually separate from Gondwana.

\section{Orogenic Cycles}

The tectonometamorphic evolution of the upper allochthon can be readily integrated with what is known from the rest of exotic terranes and the autochthon in a geodynamic model consisting of three orogenic cycles (Fig. 6). Our history starts with the subduction of old oceanic lithosphere existing in front of Gondwana, either that of the Iapetus or Tornquist Ocean, and with pulling apart of the future upper allochthon caused by slab roll-back. Arc magmatism induced the first tectonothermal event identified (D0-M0), dated at the Cambro-Ordovician boundary.

\section{Pre-Variscan Cycle}

The oldest orogenic cycle, which involved subduction, crustal thickening, and exhumation (D1-M1 and D2-M2), resulted presumably from accretion of this peri-Gondwanan terrane to a large continental mass. Its age is poorly constrained between 490 and 410 Ma (Gómez Barreiro et al., 2006; Fernández-Suárez et al., 2007). However, taking into account that in high- $P$ terranes, exhumation closely follows burial, and that the 425-410-Ma U-Pb and ${ }^{40} \mathrm{Ar} /{ }^{39} \mathrm{Ar}$ ages reflect exhumation of the high- $P$ /high- $T$ units, a Silurian-Early Devonian age is reasonable for this cycle. In the Early Silurian, Avalonia accreted to Laurentia-Baltica to form Laurussia (Lefort, 1989; Murphy et al., 2004), and this probably was the large continental mass to which the Iberian upper allochthon accreted. This first cycle is considered pre-Variscan because it is related to the closure of either the Iapetus or Tornquist Ocean, and not of the Rheic Ocean.

\section{Early Variscan Cycle}

The next cycle induced shortening and thickening followed by extension in the upper allochthon (D3-M3), where it started 
after $410 \mathrm{Ma}$, probably in the Early Devonian. During this cycle, which lasted until the Late Devonian, the oceanic lithosphere of the Rheic Ocean was imbricated and consumed, and the basal allochthon was subducted beneath the orogenic wedge previously formed at the southern margin of Laurussia. This cycle is considered early Variscan because it is related to Laurussia-Gondwana plate convergence and the closure of the Rheic Ocean, but its age (400-370 Ma in the upper allochthon, up to $360 \mathrm{Ma}$ in the ophiolites and basal allochthon; Dallmeyer et al., 1997; Rodríguez et al., 2003) is older than what is normally considered Variscan in a strict sense, that is, essentially Carboniferous.

\section{Variscan Cycle}

The continuation of Laurussia-Gondwana plate convergence once the Rheic Ocean had been closed led to the emplacement of the exotic terranes above the Iberian autochthon (D4-M4). Thrusting, dated between 340 and $320 \mathrm{Ma}$, took place over the sequences of the passive margin of Gondwana, which had been previously folded and were also shortened by thrust faults. This third cycle started in the Late Devonian, once continental subduction of the basal allochthon was blocked, and lasted during the whole Carboniferous with a fully intracontinental character. It is the only event responsible for the deformation and metamorphism in the parautochthon and autochthon, where it evolved sequentially and diachronously, prograding toward the external zones with time (Dallmeyer et al., 1997). Temperature increases resulting from crustal thickening gave rise to rheological changes in the orogenic wedge and provoked its gravitational collapse (D5-M5). Residual compressional stresses related to oblique plate convergence induced upright folding and transcurrent shearing (D6-M6).

\section{Paleogeographic Considerations}

The model presented in Figure 6 accounts for the orthogonal component of convergence between Laurussia and Gondwana. However, dextral transcurrence between these continental masses during the Devonian and Carboniferous has been widely reported (Gates et al., 1986; Rolet et al., 1994; Van Staal and De Roo, 1995; Franke and Zelazniewicz, 2002; Hatcher, 2002) and has even been considered responsible for the distribution of the different peri-Gondwanan terranes along the European Variscides (Shelley and Bossière, 2000, 2002; Stampfli et al., 2002; Martínez Catalán et al., 2007).

A reconstruction of the continental masses at the end of the Variscan cycle is shown in Figure 1, where crosscutting relationships between the Variscan and previous Paleozoic orogenic belts can be appreciated. Northwest Iberia lay adjacent to the Grand Banks of Newfoundland and close to the junction of three Paleozoic collisional belts (the Appalachians, the Scandinavian-British Caledonides, and the German-Polish Caledonides) and of the continental masses involved (Laurentia, Baltica, and Avalonia).

As can be seen in Figure 1, the European Variscides lay mostly to the south of Baltica (in present coordinates), and this reconstruction postdates the strike-slip motion between Laurussia and Gondwana. To remove the effects of dextral transcurrence, most of the Variscan belt should be moved to the upper right corner of Figure 1, thus placing it entirely to the south of Baltica, even using small strike-slip components.

This placement implies that the European part of the Variscan belt formed by collision between northern Gondwana, Baltica, and, possibly, eastern Avalonian components of Laurussia. It also suggests that the ophiolitic allochthon of northwest Iberia and equivalent units in central Europe are relicts of the eastern branch of the Rheic Ocean, that the upper allochthon was accreted to southeastern Laurussia during the pre-Variscan orogenic cycle, and that the ocean whose closure allowed the collision was Tornquist. In a general sense, the upper allochthon represents a lateral equivalent of Avalonia and its associated Gander arc, from the point of view of the time of separation from Gondwana and accretion to Laurussia. In both cases, separation took place around the Cambro-Ordovician boundary (Scotese and McKerrow, 1990; Winchester et al., 2002; Martínez Catalán et al., 2007), and accretion to Laurussia occurred in the Early Silurian (Salinian event in Newfoundland and New England; Dunning et al., 1990; Cawood et al., 1995; Hepburn et al., 1995).

Figure 7 shows a reconstruction of continents and oceans during the Paleozoic, based on Winchester et al. (2002). The possible location of the European Variscides is outlined, together with that of the exotic terrane presently preserved as the upper allochthon. To constrain these paleopositions, the presence of 1.15-Ga crust in the Eastern Desert of Egypt (Loizenbauer et al., 2001) has been taken into account, as well as the existence of a Mesoproterozoic zircon component in Cambrian sandstone of Israel (Avigad et al., 2003), in Cadomian metagranitoids of the southeast Bohemian Massif (Friedl et al., 2000, 2004), in Early Cambrian sediments of the Małopolska Massif (Belka et al., 2002), and in the Brunovistulian terrane (Hegner and Kröner, 2000). The three latter surround the eastern edge of the Bohemian Massif and are integrated in the Silesian terrane assemblage by Franke and Zelazniewicz (2002), who interpret the involved terranes as derived from Gondwana and accreted to the Baltic margin between the Cambrian and the Silurian.

The presence of a Mesoproterozoic zircon population in metasediments of the Iberian autochthon (Fernández-Suárez et al., 2000, 2002a,b; Martínez Catalán et al., 2004) may indicate a paleoposition close to the present northeastern Africa, whereas its absence (Fernández-Suárez et al., 2003) in the upper allochthon would indicate a more western derivation for this exotic terrane. The dextral component of transcurrence between Laurussia and Gondwana might have helped to superimpose the two realms that once were in lateral continuity.

\section{CONCLUSIONS}

The upper allochthon of northwest Iberia represents a periGondwanan terrane drifted away from north Africa around the Cambro-Ordovician boundary and accreted to the Baltic part of 

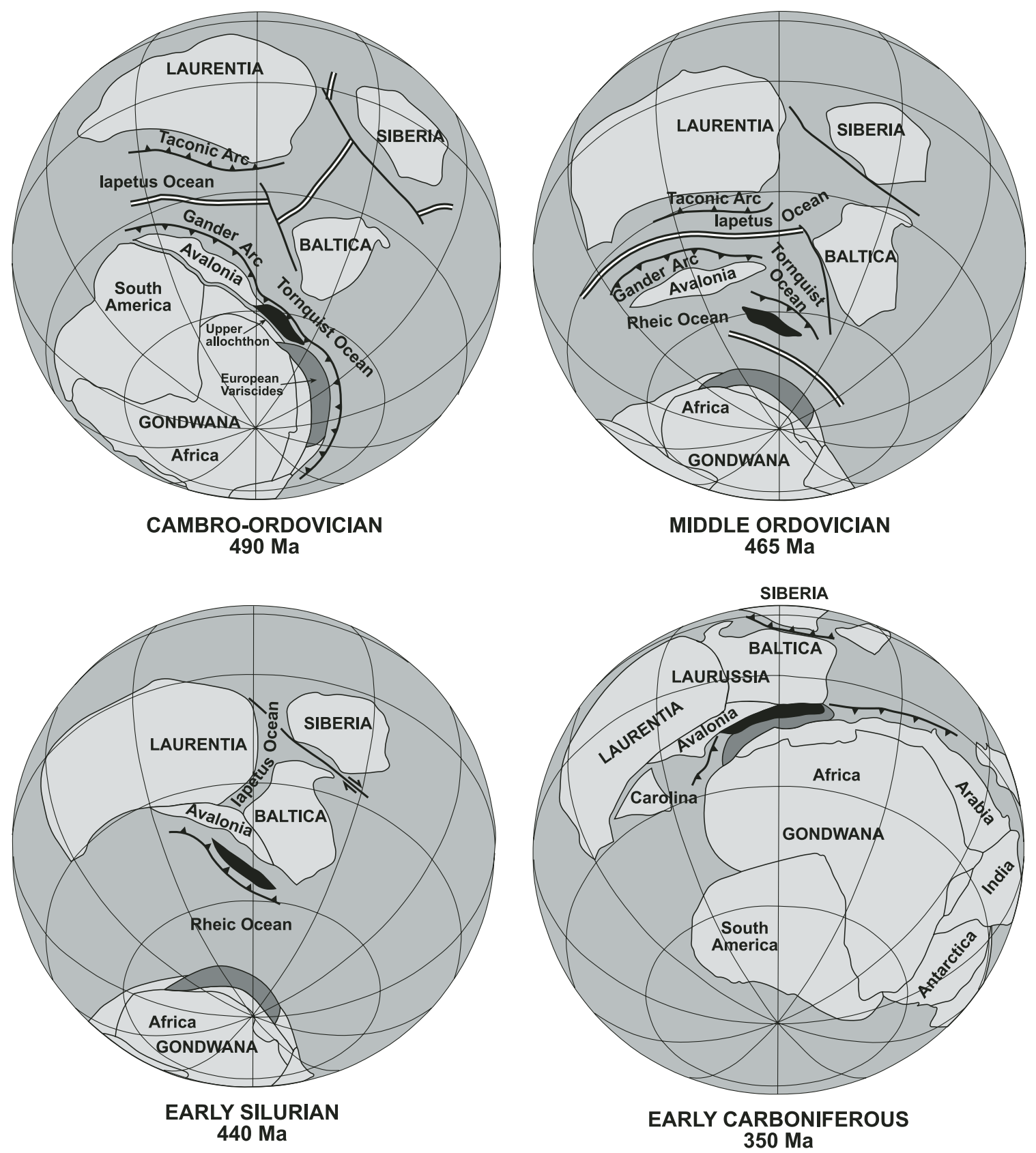

Figure 7. Schematic reconstruction of distribution of continental masses at four stages during the Paleozoic, showing the suggested paleopositions of the European Variscides (dark gray) and the exotic terrane preserved in the upper allochthon (black). Based on Winchester et al. (2002).

Laurussia probably during the Silurian. It registered three orogenic cycles: a pre-Variscan cycle related to its accretion to Laurussia and closure of the intervening Tornquist Ocean, an early Variscan cycle related to Laurussia-Gondwana convergence and closure of the eastern branch of the Rheic Ocean, and a Variscan intracontinental cycle reflecting the Laurussia-Gondwana collision. The pre-Variscan cycle has been identified only in the upper allochthon, whereas the early Variscan cycle was also registered in the ophiolitic and basal allochthons, and the Variscan cycle affected the whole allochthonous set and is the only cycle developed in the parautochthon and autochthon.

Pulling apart from Gondwana of the terrane represented by the upper allochthon was probably induced by slab roll-back of subducting Tornquist oceanic lithosphere, as the terrane registered voluminous arc plutonism, which is at the origin of an early isobaric thermal event. Subsequent burial and exhumation gave rise to a counterclockwise loop in the $P-T$ path in several units of the upper allochthon, which is related to the first, pre-Variscan oro- 
genic cycle. A second, clockwise loop is linked to the early Variscan cycle in these units, demonstrating their polyorogenic character.

Although the upper allochthon is an exotic terrane drifted away from Gondwana and later emplaced on it, the site of derivation probably differs from that of emplacement. Paleogeographic considerations using available $\mathrm{U}-\mathrm{Pb}$ zircon ages are compatible with a paleoposition of the northwest Iberian autochthon close to the present northeast Africa and a more western derivation for the upper allochthon. These positions are in agreement with Variscan convergence involving a component of dextral transcurrence.

\section{ACKNOWLEDGMENTS}

This contribution was made possible by funds provided by the Spanish Government agencies Dirección General de Investigación Científica y Técnica and Dirección General de Educacion Superior e Investigación Científica throughout the years and includes data from projects PB97-0234-C02, BTE20010963-C02 and CGL2004-04306-CO2/BTE. JGB acknowledges a postdoctoral fellowship from the Spanish Ministerio de Educación y Ciencia (grant EX2005-0490). The article has benefited from constructive reviews by J. von Raumer and F. Neubauer, and the editorial advice of G. Zulauf.

\section{REFERENCES CITED}

Abalos, B., 1997, Omphacite fabric variation in the Cabo Ortegal eclogite (NW Spain): Relationships with strain symmetry during high-pressure deformation: Journal of Structural Geology, v. 19, p. 621-637, doi: 10.1016/ S0191-8141(97)00001-1.

Abalos, B., and Aranguren, A., 1998, Anisotropy of magnetic susceptibility of eclogites: Mineralogical origin and correlation with the tectonic fabric (Cabo Ortegal, Spain): Geodinamica Acta, v. 11, p. 271-283, doi: 10.1016/S0985-3111(99)80017-5.

Abalos, B., Azcárraga, J., Gil-Ibarguchi, J.I., Mendía, M., and Santos Zalduegui, J.F., 1996, Flow stress, strain rate and effective viscosity evaluation in a high-pressure metamorphic nappe (Cabo Ortegal, Spain): Journal of Metamorphic Geology, v. 14, p. 227-248.

Abati, J., 2002, Petrología metamórfica y geocronología de la unidad culminante del Complejo de Órdenes en la región de Carballo (Galicia, NW del Macizo Ibérico): La Coruña, Spain, Laboratorio Xeolóxico de Laxe, Nova Terra, v. 20, 269 p.

Abati, J., Dunning, G.R., Arenas, R., Díaz García, F., González Cuadra, P., Martínez Catalán, J.R., and Andonaegui, P., 1999, Early Ordovician orogenic event in Galicia (NW Spain): Evidence from U-Pb ages in the uppermost unit of the Órdenes complex: Earth and Planetary Science Letters, v. 165, p. 213-228, doi: 10.1016/S0012-821X(98)00268-4.

Abati, J., Arenas, R., Martínez Catalán, J.R., and Díaz García, F., 2003, Anticlockwise $P-T$ path of granulites from the Monte Castelo gabbro (Órdenes complex, NW Spain): Journal of Petrology, v. 44, p. 305-327, doi: 10.1093/petrology/44.2.305

Andonaegui, P., González del Tánago, J., Arenas, R., Abati, J., Martínez Catalán, J.R., Peinado, M., and Díaz García, F., 2002, Tectonic setting of the Monte Castelo gabbro (Órdenes complex, northwestern Iberian Massif): Evidence for an arc-related terrane in the hanging wall to the Variscan suture, in Martínez Catalán, J.R., Hatcher, R.D., Arenas, R., and Díaz García, F., eds., Variscan-Appalachian dynamics: The building of the Late Paleozoic basement: Boulder, Colorado, Geological Society of America Special Paper 364, p. 37-56.

Araújo, A., and Ribeiro, A., 1997, Estrutura dos domínios meridionais da Zona de Ossa-Morena, in A. Araújo, A., and Pereira, M.F., eds., Estudos de Geologia da Zona de Ossa-Morena (Maciço Ibérico), Livro de homenagem ao Profesor Francisco Gonçalves: Évora, Portugal, p. 169-182.
Arenas, R., 1991, Opposite $P, T, t$ paths of Hercynian metamorphism between the upper units of the Cabo Ortegal complex and their substratum (northwest of the Iberian Massif): Tectonophysics, v. 191, p. 347-364, doi: 10.1016/0040-1951(91)90067-3.

Arenas, R., and Martínez Catalán, J.R., 1993, High-pressure and high-temperature metabasites from the Sobrado antiform (northwest of the Iberian Massif, Spain). A petrologic and field study in a granulite-eclogite transition zone: Terra abstracts, Abstract supplement 4 to Terra Nova, v. 5, p. 1.

Arenas, R., and Martínez Catalán, J.R., 2002, Prograde development of corona textures in metagabbros of the Sobrado window (Órdenes complex, NW Iberian Massif), in Martínez Catalán, J.R., Hatcher, R.D., Arenas, R., and Díaz García, F., eds., Variscan-Appalachian dynamics: The building of the Late Paleozoic basement: Boulder, Colorado, Geological Society of America Special Paper 364, p. 73-88.

Arenas, R., Martínez Catalán, J.R., Sánchez Martínez, S., Díaz García, F., Abati, J., and Fernández-Suárez, J., 2004, Ofiolitas paleozoicas de la sutura varisca de Galicia (NW del Macizo Ibérico, España): distribución, características y significado, in Pereira, E.S., Castroviejo, R., and Ortiz, F., eds., Complejos ofiolíticos en Iberoamérica. Guías de prospección para metales preciosos: Madrid, Ciencia y Tecnología para el Desarrollo, p. 203-230.

Arenas, R., Martínez Catalán, J.R., Sánchez Martínez, S., Díaz García, F., Abati, J., Fernández-Suárez, J., Andonaegui, P., and Gómez Barreiro, J., 1997, Paleozoic ophiolites in the Variscan suture of Galicia (northwest Spain): Distribution, characteristics and meaning, in Hatcher, R.D., Jr., Carlson, M.P., McBride, J.H., and Martínez Catalán, J.R., eds., 4-D framework of continental crust: Boulder, Colorado, Geological Society of America Memoir 200, doi: 10.1130/2007.1200(00).

Avigad, D., Kolodner, K., McWilliams, M., Persing, H., and Weissbrod, T., 2003, Origin of northern Gondwana Cambrian sandstone revealed by detrital zircon SHRIMP dating: Geology, v. 31, p. 227-230, doi: 10.1130/00917613(2003)031<0227:OONGCS>2.0.CO;2.

Belka, Z., Valverde-Vaquero, P., Dörr, W., Ahrendt, H., Wemmer, K., Franke, W., and Schäfer, J., 2002, Accretion of first Gondwana-derived terranes at the margin of Baltica, in Winchester, J.A., Pharaoh, T.C., and Verniers, J., eds., Palaeozoic amalgamation of central Europe: London, Geological Society of London Special Publication 201, p. 19-36.

Bellido, F., Brandle, J.L., Lasala, M., and Reyes, J., 1992, Consideraciones petrológicas y cronológicas sobre las rocas graníticas hercínicas de Galicia: Cuadernos do Laboratorio Xeolóxico de Laxe, v. 17, p. 241-261.

Caby, R., 1989, Precambrian terranes of Benin-Nigeria and northeast Brazil and the Late Proterozoic south Atlantic fit, in Dallmeyer, R.D., ed., Terranes in the circum-Atlantic Paleozoic orogens: Boulder, Colorado, Geological Society of America Special Paper 230, p. 145-158.

Capdevila, R., and Vialette, Y., 1970, Estimation radiométrique de l'âge de la deuxième phase tectonique hercynienne en Galice Moyenne (Nord-Ouest de l'Espagne): Comptes Rendus de l'Académie des Sciences, Paris, v. 270 , p. $2527-2530$.

Castiñeiras, P., 2003, Origen y evolución tectonotermal de las unidades de O Pino y Cariño (Complejos Alóctonos de Galicia) [Ph.D. thesis]: Madrid, Universidad Complutense, 281 p.

Cawood, P.A., Van Gool, J.A.M., and Dunning, G.R., 1995, Collisional tectonics along the Laurentian margin of the Newfoundland Appalachians, in Hibbard, J.P., Van Staal, C.R., and Cawood, P.A., eds., Current perspectives in the Appalachian-Caledonian orogen: St. John's, Newfoundland, Geological Association of Canada Special Paper 41, p. 283-301.

Cocks, L.R.M., and Fortey, R.A., 1988, Lower Palaeozoic facies and faunas around Gondwana, in Audley-Charles, M.G., and Hallam, A., eds., Gondwana and the Tethys: London, Geological Society of London Special Publication 37, p. 183-200.

Crowley, Q.G., Floyd, P.A., Stedrá, V., Winchester, J.A., Kachlík, V., and Holland, J.G., 2002, The Mariánské-Lázne complex, NW Bohemian Massif: Development and destruction of an early Palaeozoic seaway, in Winchester, J.A., Pharaoh, T.C., and Verniers, J., eds., Palaeozoic amalgamation of central Europe: London, Geological Society of London Special Publication 201, p. 177-195.

Dallmeyer, R.D., and Tucker, R.D., 1993, U-Pb zircon age for the Lagoa augen gneiss, Morais complex, Portugal: Tectonic implications: Journal of the Geological Society of London, v. 150, p. 405-410.

Dallmeyer, R.D., Ribeiro, A., and Marques, F., 1991, Polyphase Variscan emplacement of exotic terranes (Morais and Bragança massifs) onto Iberian successions: Evidence from ${ }^{40} \mathrm{Ar} /{ }^{39} \mathrm{Ar}$ mineral ages: Lithos, v. 27 , p. 133-144, doi: 10.1016/0024-4937(91)90025-G. 
Dallmeyer, R.D., Martínez Catalán, J.R., Arenas, R., Gil-Ibarguchi, J.I., Gutiérrez Alonso, G., Farias, P., Aller, J., and Bastida, F., 1997, Diachronous Variscan tectonothermal activity in the NW Iberian Massif: Evidence from ${ }^{40} \mathrm{Ar}{ }^{39} \mathrm{Ar}$ dating of regional fabrics: Tectonophysics, v. 277, p. 307337, doi: 10.1016/S0040-1951(97)00035-8.

Díaz García, F., 1990, La geología del sector occidental del Complejo de Órdenes (Cordillera Hercínica, NW de España): Coruña, Spain, Laboratorio Xeolóxico de Laxe, Nova Terra, v. 3, 230 p.

Díaz García, F., Arenas, R., Martínez Catalán, J.R., González del Tánago, J., and Dunning, G., 1999a, Tectonic evolution of the Careón ophiolite (northwest Spain): A remnant of oceanic lithosphere in the Variscan belt: Journal of Geology, v. 107, p. 587-605, doi: 10.1086/314368.

Díaz García, F., Martínez Catalán, J.R., Arenas, R., and González Cuadra, P., 1999b, Structural and kinematic analysis of the Corredoiras detachment: Evidence for early Variscan orogenic extension in the Órdenes complex, NW Spain: International Journal of Earth Sciences, v. 88, p. 337-351, doi: $10.1007 / \mathrm{s} 005310050269$.

Dunning, G.R., O'Brian, S.J., Colman-Sadd, S.P., Blackwood, R.F., Dickson, W.L., O'Neill, P., and Krogh, T.E., 1990, Silurian orogeny in the Newfoundland Appalachians: Journal of Geology, v. 98, p. 895-913.

Farias, P., Gallastegui, G., González-Lodeiro, F., Marquínez, J., Martín Parra, L.M., Martínez Catalán, J.R., de Pablo Maciá, J.G., and Rodríguez Fernández, L.R., 1987, Aportaciones al conocimiento de la litoestratigrafía y estructura de Galicia Central: Memórias da Faculdade de Ciências, Universidade do Porto, v. 1, p. 411-431.

Fernández-Suárez, J., Gutiérrez-Alonso, G., Jenner, G.A., and Tubrett, M.N., 1999, Crustal sources in Lower Paleozoic rocks from NW Iberia: Insights from laser ablation $\mathrm{U}-\mathrm{Pb}$ ages of detrital zircons: Journal of the Geological Society of London, v. 156, p. 1065-1068.

Fernández-Suárez, J., Gutiérrez-Alonso, G., Jenner, G.A., and Tubrett, M.N., 2000, New ideas on the Proterozoic-Early Paleozoic evolution of NW Iberia: Insights from U-Pb detrital zircon ages: Precambrian Research, v. 102, p. 185-206, doi: 10.1016/S0301-9268(00)00065-6.

Fernández-Suárez, J., Gutiérrez-Alonso, G., Cox, R., and Jenner, G.A., 2002a, Assembly of the Armorica microplate: A strike-slip terrane delivery? Evidence from U-Pb ages of detrital zircons: Journal of Geology, v. 110, p. 619-626, doi: 10.1086/341760.

Fernández-Suárez, J., Gutiérrez Alonso, G., and Jeffries, T.E., 2002b, The importance of along-margin terrane transport in northern Gondwana: Insights from detrital zircon parentage in Neoproterozoic rocks from Iberia and Brittany: Earth and Planetary Science Letters, v. 204, p. 75-88, doi: 10.1016/S0012-821X(02)00963-9.

Fernández-Suárez, J., Corfu, F., Arenas, R., Marcos, A., Martínez Catalán, J.R., Díaz García, F., Abati, J., and Fernández, F.J., 2002c, U-Pb evidence for a polyorogenic evolution of the HP-HT units of the NW Iberian Massif: Contributions to Mineralogy and Petrolology, v. 143, p. 236-253, doi: 10.1007/s00410-001-0337-2.

Fernández-Suárez, J., Díaz García, F., Jeffries, T.E., Arenas, R., and Abati, J., 2003, Constraints on the provenance of the uppermost allochthonous terrane of the NW Iberian Massif: Inferences from detrital zircon U-Pb ages: Terra Nova, v. 15, p. 138-144, doi: 10.1046/j.1365-3121.2003.00479.x.

Fernández-Suárez, J., Arenas, R., Abati, J., Martínez Catalán, J.R., Whitehouse, M.J., and Jeffries, T.E., 2007, U-Pb chronometry of polymetamorphic high-pressure granulites: An example from the allochthonous terranes of the NW Iberian Variscan belt, in Hatcher, R.D., Jr., Carlson, M.P., McBride, J.H., and Martínez Catalán, J.R., eds., 4-D framework of continental crust: Boulder, Colorado, Geological Society of America Memoir 200, doi: 10.1130/2007.1200(00).

Floor, P., 1966, Petrology of an aegirine-riebeckite gneiss-bearing part of the Hesperian Massif: The Galiñeiro and sourrounding areas, Vigo, Spain: Leidse Geologische Mededelingen, v. 36, p. 1-203.

Fonseca, P.E., 1997, Domínios meridionais da Zona de Ossa-Morena e limites com a Zona Sul Portuguesa: metamorfismo de alta pressão relacionado com a sutura Varisca Ibérica, in Araújo, A., and Pereira, M.F., eds., Estudos sobre a Geologia da Zona de Ossa-Morena (Maciço Ibérico), Livro de homenagem ao Profesor Francisco Gonçalves: Évora, Portugal, p. 133-168.

Fonseca, P.E., , Munhá, J., Pedro, J., Rosas, F., Moita, P., Araújo, A., and Leal, N., 1999, Variscan ophiolites and high-pressure metamorphism in southern Iberia: Ofioliti, v. 24, p. 259-268.

Franke, W., 2000, The mid-European segment of the Variscides: Tectonostratigraphic units, terrane boundaries and plate tectonic evolution, in Franke,
W., Haak, V., Oncken, O., and Tanner, D., eds., Orogenic processes: Quantification and modelling in the Variscan belt: London, Geological Society of London Special Publication 179, p. 35-61.

Franke, W., and Zelazniewicz, A., 2000, The eastern termination of the Variscides: Terrane correlation and kinematic evolution, in Franke, W., Haak, V., Oncken, O., and Tanner, D., eds., Orogenic processes: Quantification and modelling in the Variscan belt: London, Geological Society of London Special Publication 179, p. 63-86.

Franke, W., and Zelazniewicz, A., 2002, Structure and evolution of the Bohemian arc, in Winchester, J.A., Pharaoh, T.C., and Verniers, J., eds., Palaeozoic amalgamation of central Europe: London, Geological Society of London Special Publication 201, p. 279-293.

Friedl, G., Finger, F., McNaughton, N.J., and Fletcher, I.R., 2000, Deducing the ancestry of terranes: SHRIMP evidence for South America-derived Gondwana fragments in central Europe: Geology, v. 28, p. 1035-1038, doi: 10.1130/0091-7613(2000)028<1035:DTAOTS >2.3.CO;2.

Friedl, G., Finger, F., Paquette, J.L., von Quadt, A., McNaughton, N.J., and Fletcher, I.R., 2004, Pre-Variscan geological events in the Austrian part of the Bohemian Massif deduced from U-Pb zircon ages: International Journal of Earth Sciences, v. 93, p. 802-823, doi: 10.1007/s00531-004-0420-9.

Galán, G., and Marcos, A., 1997, Geochemical evolution of high-pressure mafic granulites from the Bacariza formation (Cabo Ortegal complex, NW Spain): An example of a heterogeneous lower crust: Geologische Rundschau, v. 86, p. 539-555, doi: 10.1007/s005310050162.

García Garzón, J., de Pablo Maciá, J.G., and Llamas Borrajo, J.F., 1981, Edades absolutas obtenidas mediante el método $\mathrm{Rb} / \mathrm{Sr}$ en dos cuerpos de ortoneises en Galicia Occidental: Boletín Geológico y Minero, v. 92, p. 463-466.

Gates, A.E., Simpson, C., and Glover, L., III, 1986, Appalachian Carboniferous dextral strike-slip faults: An example from Brookneal, Virginia: Tectonics, v. 5, p. 119-133.

Gebauer, D., 1993, Intra-grain zircon dating within the Iberian Massif: Ollo de Sapo augengneisses, bimodal gneisses from the Massif de Guilleries (Girona), graywacke of the Tentudía Group (Serie Negra, SW Spain) and the HP/HT-rock association at Cabo Ortegal (Galicia): Évora, Portugal: Comunicações da XII Reunião de Geologia do Oeste Peninsular, Universidade de Évora, v. 2, p. 41-46.

Gee, D.G., and Sturt, B.A., 1985, Scandinavian Caledonides, tectonostratigraphic map, in Gee, D.E., and Sturt, B.A., eds., The Caledonide orogen-Scandinavia and related areas: New York, John Wiley \& Sons, p. 00-00.

Gil-Ibarguchi, J.I., Mendia, M., Girardeau, J., and Peucat, J.J., 1990, Petrology of eclogites and clinopyroxene-garnet metabasites from the Cabo Ortegal complex (northwestern Spain): Lithos, v. 25, p. 133-162, doi: 10.1016/0024-4937(90)90011-O.

Girardeau, J., and Gil-Ibarguchi, I., 1991, Pyroxenite-rich peridotites of the Cabo Ortegal complex (northwestern Spain): Evidence for large-scale upper-mantle heterogeneity: Journal of Petrology, v. 32, Special Lherzolites Issue, p. 135-154.

Gómez Barreiro, J., 2003, Caracterización cinemática del contacto inferior de la Unidad de Fornás (Complejo de Órdenes, NO del Macizo Ibérico) [Ms. thesis]: Salamanca, Spain, Universidad de Salamanca, $121 \mathrm{pp}$.

Gómez Barreiro, J., 2004, La Unidad de Fornás: Evolución tectonometamórfica del SO del Complejo de Órdenes [Ph.D. thesis]: Salamanca, Spain, Universidad de Salamanca, $294 \mathrm{p}$.

Gómez Barreiro, J., Martínez Catalán, J.R., Arenas, R., and Díaz García, F., 2002, Caracterización cinemática del contacto inferior de la unidad de Fornás (Complejo de Órdenes, NW del Macizo Ibérico): Studia Geologica Salmanticensia, v. 38, p. 105-127.

Gómez Barreiro, J., Wijbrans, J.R., Castiñeiras, P., Martínez Catalán, J.R., Arenas, R., Díaz García, F., and Abati, J., 2006, ${ }^{40} \mathrm{Ar} /{ }^{39} \mathrm{Ar}$ laserprobe dating of mylonitic fabrics in a polyorogenic terrane of NW Iberia: Journal of the Geological Society of London, v. 163, p. 61-73, doi: 10.1144/0016764905-012.

González Cuadra, P., 2005, La Unidad de Corredoiras (Complejo de Órdenes, Galicia): Evolución estructural y metamórfica [Ph.D. thesis]: Salamanca, Spain, Universidad de Salamanca, 254 p.

Gradstein, F.M., Ogg, J.G., Smith, A.G., Agterberg, F.P., Bleeker, W., Cooper, R.A., Davydov, V., Gibbard, P., Hinnov, L.A., House, M.R., Lourens, L., Luterbacher, H.P., McArthur, J., Melchin, M.J., Robb, L.J., Shergold, J., Villeneuve, M., Wardlaw, B.R., Ali, J., Brinkhuis, H., Hilgen, F.J., Hooker, J., Howarth, R.J., Knoll, A.H., Laskar, J., Monechi, S., Plumb, K.A., Powell, J., Raffi, I., Röhl, U., Sadler, P., Sanfilippo, A., Schmitz, B., 
Shackleton, N.J., Shields, G.A., Strauss, H., Van Dam, J., van Kolfschoten, T., Veizer, J., and Wilson, D., 2004, A geologic time scale 2004: Cambridge, Cambridge University Press, 589 p.

Hargraves, R.B., Dawson, E.M., and Van Houten, F.B., 1987, Palaeomagnetism and age of mid-Palaeozoic ring complexes in Niger, west Africa, and tectonic implications: Geophysical Journal of the Royal Astronomical Society, v. 90, p. 705-729.

Hatcher, R.D., Jr., 2002, Alleghanian (Appalachian) orogeny, a product of zipper tectonics: Rotational, transpressive continent-continent collision and closing of ancient oceans along irregular margins, in Martínez Catalán, J.R., Hatcher, R.D., Jr., Arenas, R., and Díaz García, F., eds., VariscanAppalachian dynamics: The building of the Late Paleozoic basement: Boulder, Colorado, Geological Society of America Special Paper 364, p. 199-208.

Hegner, E., and Kröner, A., 2000, Review of Nd isotopic data and xenocrystic and detrital zircon ages from the pre-Variscan basement in the eastern Bohemian Massif: Speculations on palinspastic reconstructions, in Franke, W., Haak, V., Oncken, O., and Tanner, D., eds., Orogenic processes, quantification and modelling in the Variscan belt: London, Geological Society of London Special Publication 179, p. 113-130.

Hepburn, J.C., Dunning, G.R., and Hon, R., 1995, Geochronology and regional tectonic implications of Silurian deformation in the Nashoba terrane, southeastern New England, U.S.A., in Hibbard, J.P., Van Staal, C.R., and Cawood, P.A., eds., Current perspectives in the Appalachian-Caledonian orogen: St. John's, Newfoundland, Geological Association of Canada Special Paper 41, p. 349-366.

Holdaway, M.J., 1971, Stability of andalusite and the aluminum silicate phase diagram: American Journal of Science, v. 271, p. 97-131.

Hubregtse, J.J.M.W., 1973, Petrology of the Mellid area, a Precambrian polymetamorphic rock complex, Galicia, N.W. Spain: Leidse Geologische Mededelingen, v. 49, p. 9-31.

Iglesias Ponce de León, M., and Choukroune, P., 1980, Shear zones in the Iberian arc: Journal of Structural Geology, v. 2, p. 63-68, doi: 10.1016/01918141(80)90035-8

Julivert, M., Fontboté, J.M., Ribeiro, A., and Conde, L., 1972, Mapa Tectónico de la Península Ibérica y Baleares, Escala 1: 1.000.000: Madrid, Spain, Instituto Geológico y Minero de España

Kent, D.V., Dia, O., and Sougy, J.M.A., 1984, Paleomagnetism of Lower-Middle Devonian and Upper Proterozoic-Cambrian(?) rocks from Mejeria (Mauritania, west Africa), in Van der Voo, R., Scotese, C.R., and Bonhommet, N., eds., Plate reconstruction from Paleozoic paleomagnetism: Washington, D.C., American Geophysical Union Geodynamics Series 12, p. $99-115$.

Kuijper, R.P., 1980, Precambrian U-Pb zircon ages from western Galicia (NW Spain): Earth Sciences Review, v. 16, p. 313-316, doi: 10.1016/00128252(80)90051-3.

Lancelot, J.R., Allegret, A., and Iglesias-Ponce de León, M., 1985, Outline of Upper Precambrian and Lower Paleozoic evolution of the Iberian Peninsula according to U-Pb dating of zircons: Earth and Planetary Sciences Letters, v. 74, p. 325-337

Leal, N., Pedro, J., Moita, P., Fonseca, P., Araújo, A., and Munhá, J., 1996 Metamorfismo dos sectores meridionais da Zona de Ossa-Morena: actualização de conhecimentos, in A. Araújo, A., and Pereira, M.F., eds., Estudos de Geologia da Zona de Ossa-Morena (Maciço Ibérico), Livro de homenagem ao Profesor Francisco Gonçalves: Évora, Portugal, p. 119-132.

Ledru, P., Costa, S., and Echtler, H., 1994, The Massif Central, structure, in Keppie, J.D., ed., Pre-Mezozoic geology in France and related areas, Part III: Berlin, Springer-Verlag, p. 305-323.

Lefort, J.P., 1989, Basement correlation across the north Atlantic: Berlin, Springer-Verlag, $148 \mathrm{p}$.

Llana-Fúnez, S., and Marcos, A., 2001, The Malpica-Lamego line: A major crustal-scale shear zone in the Variscan belt of Iberia: Journal of Structural Geology, v. 23, p. 1015-1030, doi: 10.1016/S0191-8141(00)00173-5.

Loizenbauer, J., Wallbrecher, E., Fritz, H., Neumayr, P., Khudeir, A.A., and Kloetzli, U., 2001, Structural geology, single zircon ages and fluid inclusion studies of the Meatiq metamorphic core complex: Implications for Neoproterozoic tectonics in the Eastern Desert of Egypt: Precambrian Research, v. 110, p. 357-383, doi: 10.1016/S0301-9268(01)00176-0.

Marcos, A., Farias, P., Galán, G., Fernández, F.J., and Llana-Fúnez, S., 2002, Tectonic framework of the Cabo Ortegal complex: A slab of lower crust exhumed in the Variscan orogen (northwestern Iberian Peninsula), in Martínez Catalán, J.R., Hatcher, R.D., Arenas, R., and Díaz García, F., eds., Variscan-Appalachian dynamics: The building of the Late Paleozoic basement: Boulder, Colorado, Geological Society of America Special Paper 364, p. 125-142.

Martínez Catalán, J.R., Arenas, R., Díaz García, F., Rubio Pascual, F.J., Abati, J., and Marquínez, J., 1996, Variscan exhumation of a subducted Paleozoic continental margin: The basal units of the Órdenes complex, Galicia: NW Spain: Tectonics, v. 15, p. 106-121, doi: 10.1029/95TC02617.

Martínez Catalán, J.R., Arenas, R., Díaz García, F., and Abati, J., 1997, Variscan acretionary complex of northwest Iberia: Terrane correlation and succession of tectonothermal events: Geology, v. 25, p. 1103-1106, doi: 10.1130/0091-7613(1997)025<1103:VACONI >2.3.CO;2.

Martínez Catalán, J.R., Arenas, R., Díaz García, F., and Abati, J., 1999, Allochthonous units in the Variscan belt of NW Iberia. Terranes and accretionary history, in Sinha, A.K., ed., Basement tectonics 13: Dordrecht, Kluwer, p. $65-84$.

Martínez Catalán, J.R., Díaz García, F., Arenas, R., Abati, J., Castiñeiras, P., González Cuadra, P., Gómez Barreiro, J., and Rubio Pascual, F., 2002 Thrust and detachment systems in the Ordenes complex (northwestern Spain): Implications for the Variscan-Appalachian geodynamics, in Martínez Catalán, J.R., Hatcher, R.D., Arenas, R., and Díaz García, F., eds., Variscan-Appalachian dynamics: The building of the Late Paleozoic basement: Boulder, Colorado, Geological Society of America Special Paper 364, p. 163-182.

Martínez Catalán, J.R., Fernández-Suárez, J., Jenner, G.A., Belousova, E., and Díez Montes, A., 2004, Provenance constraints from detrital zircon U-Pb ages in the NW Iberian Massif: Implications for Paleozoic plate configuration and Variscan evolution: Journal of the Geological Society of London, v. 161, p. 461-473

Martínez Catalán, J.R., Arenas, R., Díaz García, F., Gómez Barreiro, J., Gónzalez Cuadra, P., Abati, J., Castiñeiras, P., Fernández-Suárez, J., Sánchez Martínez, S., Andonaegui, P., Gónzalez Clavijo, E., Díez Montes, A., Rubio Pascual, F.J., and Valle Aguado, B., (2007), Space and time in the tectonic evolution of the northwestern Iberian Massif. Implications for the comprehension of the Variscan belt, in Hatcher, R.D., Jr., Carlson, M.P., McBride, J.H., and Martínez Catalán, J.R., eds., 4-D framework of continental crust: Boulder, Colorado, Geological Society of America Memoir 200, doi: 10.1130/2007.1200(00)

Matte, Ph., and Capdevila, R., 1978, Tectonique en grands plis couchés et plissements superposés d'âge hercynien dans la série de Órdenes-Betanzos (Galice Occidentale): Coruña, Spain: Cuadernos del Seminario de Estudios Cerámicos de Sargadelos, v. 27, p. 193-201.

Mendia Aranguren, M.S., 2000, Petrología de la Unidad Eclogítica del Complejo de Cabo Ortegal (NW de España): La Coruña, Spain, Laboratorio Xeolóxico de Laxe, Nova Terra, v. 16, 424 p.

Murphy, J.B., Fernández-Suárez, J., Keppie, J.D., and Jeffries, T.E., 2004 Contiguous rather than discrete Paleozoic histories for the Avalon and Meguma terranes based on detrital zircon data: Geology, v. 32, p. 585588, doi: 10.1130/G20351.1.

Neubauer, F., Hoinkes, G., Sassi, F.P., Handler, R., Höck, V., Koller, F., and Frank, W., 1999, Pre-Alpine metamorphism of the eastern Alps: Schweizerische Mineralogische und Petrographische Mitteilungen, v. 79, p. 41-62.

Neuman, R.B., and Max, M.D., 1989, Penobscottian-Grampian-Finnmarkian orogenies as indicators of terrane linkages, in Dallmeyer, R.D., ed., Terranes in the circum-Atlantic Paleozoic orogens: Boulder, Colorado, Geological Society of America Special Paper 230, p. 31-45.

Ordóñez Casado, B., Gebauer, D., Schäfer, H.J., Gil-Ibarguchi, J.I., and Peucat, J.J., 2001, A single Devonian subduction event for the HP/HT metamorphism of the Cabo Ortegal complex within the Iberian Massif: Tectonophysics, v. 332, p. 359-385, doi: 10.1016/S0040-1951(00)00210-9.

Ortega, L.A., Carracedo, M., Larrea, F.J., and Gil-Ibarguchi, J.I., 1996, Geochemistry and tectonic environment of volcanosedimentary rocks from the Ollo de Sapo Formation (Iberian Massif, Spain), in Demaiffe, D., ed., Petrology and geochemistry of magmatic suites of rocks in the continental and oceanic crusts: Brussels, Université Libre de Bruxelles, p. 277-290.

Paris, F., and Robardet, M., 1990, Early Paleozoic paleobiogeography of the Variscan regions: Tectonophysics, v. 177, p. 193-213, doi: 10.1016/00401951(90)90281-C

Peacock, S.M., 1990, Numerical simulation of metamorphic pressure-temperature-time paths and fluid production in subducting slabs: Tectonics, v. 9 p. $1197-1211$.

Peacock, S.M., 1991, Numerical simulation of subduction zone pressure-temperature-time paths: Constraints on fluid production and arc magmatism: 
Philosophical Transactions of the Royal Society, London, v. A335, p. 341-353.

Peucat, J.J., Bernard-Griffiths, J., Gil-Ibarguchi, J.I., Dallmeyer, R.D., Menot, R.P., Cornichet, J., and Iglesias Ponce de León, M., 1990, Geochemical and geochronological cross section of the deep Variscan crust: The Cabo Ortegal high-pressure nappe (northwestern Spain): Tectonophysics, v. 177, p. 263-292, doi: 10.1016/0040-1951(90)90285-G.

Pin, C., Ortega Cuesta, L.A., and Gil-Ibarguchi, J.I., 1992, Mantle-derived, early Paleozoic A-type metagranitoids from the NW Iberian Massif: Nd isotope and trace-element constraints: Bulletin de la Société Géologique de France, v. 163, p. 483-494.

Pin, C., Paquette, J.L., Santos Zalduegui, J.F., and Gil-Ibarguchi, J.I., 2002, Early Devonian supra-subduction zone ophiolite related to incipient collisional processes in the western Variscan belt: The Sierra de Careón unit, Órdenes complex, Galicia, in Martínez Catalán, J.R., Hatcher, R.D., Arenas, R., and Díaz García, F., eds., Variscan-Appalachian dynamics: The building of the Late Paleozoic basement: Boulder, Colorado, Geological Society of America Special Paper 364, p. 57-72.

Ploquin, A., and Santallier, D., 1994, The Massif Central, igneous activity, Caledono-Hercynian magmatism in the French Massif Central. Introduction, in Keppie, J.D., ed., Pre-Mezozoic geology in France and related areas, Part III: Berlin, Springer-Verlag, p. 341-343.

Rey, P., Burg, J.P., and Casey, M., 1997, The Scandinavian Caledonides and their relationship to the Variscan belt, in Burg, J.P., and Ford, M., eds., Orogeny through time: London, Geological Society of London Special Publication 121, p. 179-200.

Ribeiro, A., Pereira, E., and Dias, R., 1990, Central-Iberian zone. Allochthonous sequences. Structure in the northwest of the Iberian Peninsula, in Dallmeyer, R.D., and Martínez García, E., eds., Pre-Mesozoic geology of Iberia: Berlin, Springer-Verlag, p. 220-236.

Ries, A.C., 1979, Variscan metamorphism and K-Ar dates in the Variscan fold belt of S Brittany and NW Spain: Journal of the Geological Society of London, v. 136, p. 89-103.

Robardet, M., 2002, Alternative approach to the Variscan belt of southwestern Europe: Preorogenic paleobiogeographical constraints, in Martínez Catalán, J.R., Hatcher, R.D., Arenas, R., and Díaz García, F., eds., VariscanAppalachian dynamics: The building of the Late Paleozoic basement: Boulder, Colorado, Geological Society of America Special Paper 364, p. $1-15$.

Robardet, M., 2003, The Armorica "microplate": Fact or fiction? Critical review of the concept and contradictory paleobiogeographical data: Palaeogeography, Palaeoclimatology, Palaeoecology, v. 195, p. 125-148, doi: 10.1016/S0031-0182(03)00305-5.

Robardet, M., Paris, F., and Racheboeuf, P.R., 1990, Paleogeographic evolution of southwestern Europe during Early Paleozoic times, in McKerrow, W.S., and Scotese, C.R., eds., Paleozoic palaeogeography and biogeography: London, Geological Society of London Memoir 12, p. 411-419.

Roberts, D., and Gee, D.G., 1985, An introduction to the structure of the Scandinavian Caledonides, in Gee, D.E., and Sturt, B.A., eds., The Caledonide orogen-Scandinavia and related areas: New York, John Wiley \& Sons, p. $55-68$.

Rocci, G., Bronner, G., and Deschamps, M., 1991, Crystalline basement of the west African craton, in Dallmeyer, R.D., and Lécorché, J.P., eds., The west African orogens and circum-Atlantic correlatives: Berlin, SpringerVerlag, p. 31-61.

Rodríguez, J., Cosca, M.A., Gil-Ibarguchi, J.I., and Dallmeyer, R.D., 2003 , Strain partitioning and preservation of ${ }^{40} \mathrm{Ar} /{ }^{39} \mathrm{Ar}$ ages during Variscan exhumation of a subducted crust (Malpica-Tui complex, NW Spain): Lithos, v. 70, p. 111-139, doi: 10.1016/S0024-4937(03)00095-1.

Roger, F., and Matte, Ph., 2005, Early Variscan HP metamorphism in the western Iberian Allochthon-A $390 \mathrm{Ma}$ U-Pb age for the Bragança eclogite (NW Portugal): International Journal of Earth Sciences, v. 94, p. 173-179, doi: 10.1007/s00531-005-0466-3.

Rolet, J., Gresselin, F., Jegouzo, P., Ledru, P., and Wyns, R., 1994, Intracontinental Hercynian events in the Armorican Massif, structure and metamorphism, the Variscan orogeny in the Armorican Massif, in Keppie, J.D., ed., Pre-Mesozoic geology in France and related areas: Berlin, SpringerVerlag, p. 195-219.

Sánchez Martínez, S., Arenas, R., Andonaegui, P., Martínez Catalán, J.R., and Pearce, J.A., (2007), Geochemistry of two associated ophiolites from the Cabo Ortegal complex (Variscan belt of northwest Spain), in Hatcher, R.D., Jr., Carlson, M.P., McBride, J.H., and Martínez Catalán, J.R., eds.,
4-D framework of continental crust: Boulder, Colorado, Geological Society of America Memoir 200, doi: 10.1130/2007.1200(00).

Santallier, D., Lardeaux, J.M., Marchand, J., and Marignac, Ch., 1994, The Massif Central, metamorphism, in Keppie, J.D., ed., Pre-Mezozoic geology in France and related areas, Part III: Berlin, Springer-Verlag, p. 324-340.

Santos, J.F., Schärer, U., Gil-Ibarguchi, J.I., and Girardeau, J., 2002, Genesis of pyroxenite-rich peritotite at Cabo Ortegal (NW Spain): Geochemical and $\mathrm{Pb}-\mathrm{Sr}-\mathrm{Nd}$ isotope data: Journal of Petrology, v. 43, p. 17-43, doi: 10.1093/petrology/43.1.17

Santos Zalduegui, J.F., Schärer, U., and Gil-Ibarguchi, J.I., 1995, Isotope constraints on the age and origin of magmatism and metamorphism in the Malpica-Tuy allochthon, Galicia, NW-Spain: Chemical Geology, v. 121, p. 91-103, doi: 10.1016/0009-2541(94)00123-P.

Santos Zalduegui, J.F., Schärer, U., Gil-Ibarguchi, J.I., and Girardeau, J., 1996, Origin and evolution of the Paleozoic Cabo Ortegal ultramafic-mafic complex (NW Spain): U-Pb, $\mathrm{Rb}-\mathrm{Sr}$ and $\mathrm{Pb}-\mathrm{Pb}$ isotope data: Chemical Geology, v. 129, p. 281-304, doi: 10.1016/0009-2541(95)00144-1.

Schäfer, H.J., Gebauer, D., Gil-Ibarguchi, J.I., and Peucat, J.J., 1993, Ion-microprobe U-Pb zircon dating on the HP/HT Cabo Ortegal complex (Galicia, NW Spain): Preliminary results: Terra Abstracts, v. 5, no. 4, p. 22.

Scotese, C.R., 1984, Paleozoic paleomagnetism and the assembly of Pangea, in Van der Voo, R., Scotese, C.R., and Bonhommet, N., eds., Plate reconstruction from Paleozoic paleomagnetism: Washington, D.C., American Geophysical Union Geodynamic Series 12, p. 1-10.

Scotese, C.R., and McKerrow, W.S., 1990, Revised world maps and introduction, in McKerrow, W.S., and Scotese, C.R., eds., Paleozoic paleogeography and biogeography: London, Geological Society of London Memoir 12 , p. $1-22$.

Shelley, D., and Bossière, G., 2000, A new model for the Hercynian orogen of Gondwanan France and Iberia: Journal of Structural Geology, v. 22, p. 757-776, doi: 10.1016/S0191-8141(00)00007-9.

Shelley, D., and Bossière, G., 2002, Megadisplacements and the Hercynian orogen of Gondwanan France and Iberia, in Martínez Catalán, J.R., Hatcher, R.D., Arenas, R., and Díaz García, F., eds., Variscan-Appalachian dynamics: The building of the Late Paleozoic basement: Boulder, Colorado, Geological Society of America Special Paper 364, p. 209-222.

Stampfli, G.M., and Borel, G.D., 2002, A plate tectonic model for the Paleozoic and Mesozoic constrained by dynamic plate boundaries and restored synthetic oceanic isochrons: Earth and Planetary Sciences Letters, v. 196, p. 17-33, doi: 10.1016/S0012-821X(01)00588-X.

Stampfli, G.M., von Raumer, J.F., and Borel, G.D., 2002, Paleozoic evolution of pre-Variscan terranes: From Gondwana to the Variscan collision, in Martínez Catalán, J.R., Hatcher, R.D., Arenas, R., and Díaz García, F., eds., Variscan-Appalachian dynamics: The building of the Late Paleozoic basement: Boulder, Colorado, Geological Society of America Special Paper 364, p. 263-280.

Stephens, B., and Gee, D.G., 1989, Terranes and polyphase accretionary history in the Scandinavian Caledonides, in Dallmeyer, R.D. ed., Terranes in the circum-Atlantic Paleozoic orogens: Boulder, Colorado, Geological Society of America Special Paper 230, p. 17-30.

Valverde Vaquero, P., and Dunning, G.R., 2000, New U-Pb ages for Early Ordovician magmatism in central Spain: Journal of the Geological Society of London, v. 157, p. 15-26.

Van Calsteren, P.W.C., Boelrijk, N.A.I.M., Hebeda, E.H., Priem, H.N.A., Den Tex, E., Verdurmen, E.A.T.H., and Verschure, R.H., 1979, Isotopic dating of older elements (including the Cabo Ortegal mafic-ultramafic complex) in the Hercynian orogen of NW Spain: Manifestations of a presumed Early Paleozoic mantle-plume: Chemical Geology, v. 24, p. 35-56, doi: 10.1016/0009-2541(79)90011-1.

Vanderhaeghe, O., and Teyssier, C., 2001, Crustal-scale rheological transitions during late-orogenic collapse: Tectonophysics, v. 335, p. 211-228, doi: 10.1016/S0040-1951(01)00053-1.

Van der Voo, R., 1982, Pre-Mesozoic paleomagnetism and plate tectonics: Annual Reviews of Earth and Planetary Science, v. 10, p. 191-220.

Van der Voo, R., 1988, Paleozoic paleogeography of North America, Gondwana, and intervening displaced terranes: Comparisons of paleomagnetism with paleoclimatology and biogeographical patterns: Geological Society of America Bulletin, v. 100, p. 311-324, doi: 10.1130/00167606(1988) $100<0311:$ PPONAG $>2.3 . C O ; 2$.

Van Staal, C.R., and De Roo, J.A., 1995, Mid-Paleozoic tectonic evolution of the Appalachian central mobile belt in northern New Brunswick, Canada: Collision, extensional collapse and dextral transpression, in Hibbard, 
J.P., Van Staal, C.R., and Cawood, P.A., eds., Current perspectives in the Appalachian-Caledonian orogen: St. John's, Newfoundland, Geological Association of Canada Special Paper 41, p. 367-389.

Van Zuuren, A., 1969, Structural petrology of an area near Santiago de Compostela (NW Spain): Leidse Geologische Mededelingen, v. 45, p. 1-71.

Vialette, Y., Casquet, C., Fúster, J.M., Ibarrola, E., Navidad, M., Peinado, M., and Villaseca, C., 1987, Geochronological study of orthogneisses from the Sierra de Guadarrama (Spanish central system): Neues Jahrbuch für Mineralogie Monatshefte, v. 10, p. 465-479.

Vogel, D.E., 1967, Petrology of an eclogite- and pyrigarnite-bearing polymetamorphic rock complex at Cabo Ortegal: NW Spain: Leidse Geologische Mededelingen, v. 40, p. 121-213. von Raumer, J.F., Stampfli, G.M., and Bussy, F., 2003, Gondwana-derived microcontinents-The constituents of the Variscan and Alpine collisional orogens: Tectonophysics, v. 365, p. 7-22, doi: 10.1016/S00401951(03)00015-5.

Winchester, J.A., Pharaoh, T.C., and Verniers, J., 2002, Palaeozoic amalgamation of central Europe: An introduction and synthesis of new results from recent geological and geophysical investigations, in Winchester, J.A. Pharaoh, T.C., and Verniers, J., eds., Palaeozoic amalgamation of central Europe: London, Geological Society of London Special Publication 201, p. $1-18$. 